\title{
Stem Cells Expanded from the Human Embryonic Hindbrain Stably Retain Regional Specification and High Neurogenic Potency
}

\author{
Jignesh Tailor, ${ }^{1,2}$ Raja Kittappa, ${ }^{1}$ Ketty Leto, ${ }^{5,6}$ Monte Gates, ${ }^{7}$ Melodie Borel, ${ }^{3}$ Ole Paulsen, ${ }^{3}$ Sonia Spitzer, ${ }^{1,4}$ \\ Ragnhildur Thora Karadottir, ${ }^{1,4}$ Ferdinando Rossi, ${ }^{5,6}$ Anna Falk, ${ }^{1}$ and Austin Smith ${ }^{1,2}$ \\ ${ }^{1}$ Wellcome Trust-Medical Research Council Stem Cell Institute, ${ }^{2}$ Department of Biochemistry, ${ }^{3}$ Department of Physiology, Development and Neuroscience, \\ and ${ }^{4}$ Department of Veterinary Medicine, University of Cambridge, Cambridge CB21QR, United Kingdom, ${ }^{5}$ Department of Neuroscience and ${ }^{6}$ Neuroscience \\ Institute Cavaleieri-Ottolenghi, University of Turin, 10043 Torino, Italy, and 'Institute for Science and Technology in Medicine, Keele University, Keele, \\ Staffordshire ST5 5BG, United Kingdom
}

Stem cell lines that faithfully maintain the regional identity and developmental potency of progenitors in the human brain would create new opportunities in developmental neurobiology and provide a resource for generating specialized human neurons. However, to date, neural progenitor cultures derived from the human brain have either been short-lived or exhibit restricted, predominantly glial, differentiation capacity. Pluripotent stem cells are an alternative source, but to ascertain definitively the identity and fidelity of cell types generated solely in vitro is problematic. Here, we show that hindbrain neuroepithelial stem (hbNES) cells can be derived and massively expanded from early human embryos (week 5-7, Carnegie stage 15-17). These cell lines are propagated in adherent culture in the presence of EGF and FGF2 and retain progenitor characteristics, including SOX1 expression, formation of rosette-like structures, and high neurogenic capacity. They generate GABAergic, glutamatergic and, at lower frequency, serotonergic neurons. Importantly, hbNES cells stably maintain hindbrain specification and generate upper rhombic lip derivatives on exposure to bone morphogenetic protein (BMP). When grafted into neonatal rat brain, they show potential for integration into cerebellar development and produce cerebellar granule-like cells, albeit at low frequency. hbNES cells offer a new system to study human cerebellar specification and development and to model diseases of the hindbrain. They also provide a benchmark for the production of similar long-term neuroepithelial-like stem cells (lt-NES) from pluripotent cell lines. To our knowledge, hbNES cells are the first demonstration of highly expandable neuroepithelial stem cells derived from the human embryo without genetic immortalization.

\section{Introduction}

Following pioneering studies in rodents (reviewed by McKay, 1997), various strategies have been applied to propagate neural progenitors from the human brain. Early studies relied on genetic immortaliza-

\footnotetext{
Received Jan. 9, 2013; revised May 9, 2013; accepted June 5, 2013.

Author contributions: J.T., R.K., O.P., R.T.K., F.R., A.F., and A.S. designed research; J.T., K.L., M.G., M.B., S.S., and A.F. performed research; M.G. contributed unpublished reagents/analytic tools; J.T., K.L., and A.F. analyzed data; J.T., F.R., and A.S. wrote the paper.

This work was supported by NeuroStemcell (European Community Seventh Framework Programme Grant 222943) and the Medical Research Council of the United Kingdom. J.T. was supported by the National Institute of Health Research, United Kingdom and the Raymond and Beverly Sackler Fellowship. K.L. is recipient of Fondo di Incentivazione della Ricerca di Base (FIRB) Research Grant RBFR10A01S by the Italian Ministry for University and Research. A.S. is a Medical Research Council Professor. We thank Peter Humphreys for support with imaging; Nigel Miller for flow cytometry; Margaret McLeish for histological sections; James Clarke and Melanie Rittirsch for technical assistance; Matthew Trotter, Sabine Dietmann, and Patrick Lombard for bioinformatic support; Roger Barker for facilitating access to fetal tissue; Rosalind Segal and Johan Ericson for providing antibodies; Paul Bertone for RNA samples; and Yasuhiro Takashima, Masaki Kinoshita, and Jörg Betschinger for PiggyBac constructs and advice.

The authors declare no competing financial interests.

Correspondence should be addressed to either of the following: Dr. Austin Smith, Wellcome Trust Medical Research Council Stem Cell Institute, Tennis Court Road, Cambridge CB2 1QR, United Kingdom, E-mail: austin.smith@cscr.cam.ac.uk; or Dr. Anna Falk, Department of Neuroscience, Karolinska Institutet, Retzius v. 8, S-17177 Stockholm, Sweden, E-mail: Anna.falk@ki.se.

A. Falk's present address: Department of Neuroscience, Karolinska Institutet, S-17177 Stockholm, Sweden. DOI:10.1523/JNEUROSCI.0130-13.2013

Copyright $\odot 2013$ the authors $\quad 0270-6474 / 13 / 3312407-16 \$ 15.00 / 0$
}

tion with oncogenes, such as v-myc (Sah et al., 1997). However, oncogenes subvert normal regulation of growth and differentiation. Culture of micro-dissected human fetal tissue as free-floating aggregates called neurospheres allows proliferation of neural progenitors in response to mitogens without genetic manipulation (Svendsen et al., 1998; Carpenter et al., 1999; Vescovi et al., 1999). However, these cultures are heterogeneous, and passaging may be accompanied by progressive loss of stem cells and neurogenic capacity (Suslov et al., 2002; Reynolds and Rietze, 2005).

Monolayer cultures of human neural progenitors from fetal (Yan et al., 2007) and adult brain (Walton et al., 2006) have been reported, but long-term stability, regional identity, or developmental potential was not described. We previously found that neural stem (NS) cells from human fetal forebrain or spinal cord expanded in adherent culture (Sun et al., 2008) exhibit molecular markers suggestive of radial glia or outer subventricular zone progenitors. These cell lines remain neurogenic but appear restricted to generation of a subset of GABAergic neurons.

Human embryonic stem (ES) cells or induced pluripotent stem (iPS) cells are an ex vivo source of neural progenitors. During human pluripotent stem cell differentiation, neural progenitors exhibit spontaneous self-organization into transient structures termed "neural rosettes." Rosette stage cells are re- 
sponsive to patterning signals (Elkabetz et al., 2008; Chambers et al., 2009). If isolated, they can give rise to stable cell lines in the presence of growth factors (Koch et al., 2009). These rosette-like stem cells exhibit morphological and gene expression markers of neuroepithelial progenitors and are molecularly distinct from radial glia-like NS cells (Falk et al., 2012). They have been named long-term neuroepithelial-like stem (lt-NES) cells. However, the true identity and physiological relevance of cells derived in vitro from pluripotent sources are open to question because cells could acquire transcriptional and epigenetic programs in vitro that diverge from cell states in vivo (Conti and Cattaneo, 2010). Although expanded lt-NES cells display a positional marker profile indicative of anterior hindbrain (Falk et al., 2012), how faithfully they recapitulate the specification of neuroepithelial cells in the embryonic brain is uncertain because their antecedents, pluripotent stem cell-derived neural rosettes and early passage derivatives, express anterior forebrain markers (Koch et al., 2009).

Here, we investigate the capacity of neuroepithelial cells from the human embryonic hindbrain at different developmental stages for long-term maintenance in adherent culture. We define the stage-specific origin and regional identity of stable stem cell lines and investigate their potency for cerebellar lineage differentiation in vitro and in vivo.

\section{Materials and Methods}

Ethics statement. All studies with human tissue were performed under ethical approval from the Cambridgeshire Research Ethics Committee (Reference 96/085) using tissue donated with informed consent after elective termination of pregnancy. The storage and use of human tissue were approved by the Human Tissue Authority, United Kingdom (License 12196).

Hindbrain NES cell derivation. Aborted human embryos $(n=18)$ of either sex were staged using the Carnegie staging system (O'Rahilly and Muller, 1987). Human hindbrain at embryonic day 35-60 (Carnegie stages 15-23) was dissected in DMEM/F12 media (Invitrogen) with $2 \mathrm{~mm}$ L-glutamine (Invitrogen) and modified N2 supplement (Ying and Smith, 2003) (henceforth called N2 medium), and the meninges removed. The tissue was incubated in $\mathrm{N} 2$ medium with trypsin $(0.05 \%)$ at $37^{\circ} \mathrm{C}$ for 2 min and carefully dissociated by pipetting up and down every $30 \mathrm{~s}$ until a single-cell suspension was formed. N2 medium with trypsin inhibitor (2 $\mathrm{mg} / \mathrm{ml} ; \sigma \mathrm{T}$-2011) was added in equal volume, and the cell suspension was then washed with $10 \times$ volume of N2 medium and centrifuged at $300 \times g$ for $3 \mathrm{~min}$. The supernatant was removed and the cell pellet resuspended in N2 medium with B27 (1:1000), EGF (10 ng/ml), FGF2 $(10 \mathrm{ng} / \mathrm{ml})$, and penicillin-streptomycin (1:100, Invitrogen) (henceforth called EF medium). The cells were then plated into dishes coated with poly-L-ornithine $\left(20-30 \mathrm{~min}\right.$ at $37^{\circ} \mathrm{C}, 0.1 \mu \mathrm{g} / \mathrm{ml}$, Sigma) and laminin $\left(4-12 \mathrm{~h}\right.$ at $37^{\circ} \mathrm{C}, 10 \mu \mathrm{g} / \mathrm{ml}$, Sigma) in EF medium. Medium was changed $12 \mathrm{~h}$ after plating, and the cells were passaged using $0.25 \%$ trypsin within $3 \mathrm{~d}$ and replated to obtain a monolayer of cells at a density of $4-5 \times 10^{4}$ cells $/ \mathrm{cm}^{2}$. Half of the media was changed every $2-3 \mathrm{~d}$ to allow culture conditioning. This was discontinued after 3 passages.

Maintenance and differentiation of NES cell lines. Culture flasks were coated with poly-L-ornithine $(0.1 \mathrm{mg} / \mathrm{ml}$, Sigma) for $20-30 \mathrm{~min}$, washed twice with PBS, and then coated with laminin (10 $\mu \mathrm{g} / \mathrm{ml}$, Sigma) for 4-6 h. Cells were expanded in EF medium and split 1:3 approximately every $3 \mathrm{~d}$ with TrypLE express (Invitrogen). For cryopreservation, cells were trypsinized and $\sim 2 \times 10^{6}$ cells were pelleted $(300 \mathrm{~g})$ and resuspended in cryopreservation medium containing $10 \%$ DMSO and $90 \%$ culture medium before controlled freezing at $-1^{\circ} \mathrm{C}$ per minute. Cells were rapidly thawed at $37^{\circ} \mathrm{C}$, resuspended in prewarmed culture media, centrifuged for $3 \mathrm{~min}$ at $300 \times \mathrm{g}$, resuspended in EF medium, and replated on polyL-ornithine and laminin-coated plates. For neuronal differentiation, cells were plated at a density of $4 \times 10^{4}$ cells $/ \mathrm{cm}^{2}$ in poly-ornithine and laminin-coated flasks in N2 medium with B27 supplement (1:1000) and no additional growth factors (base medium). For neuronal differentia-
Table 1. Relevant genes, primers, and probes

\begin{tabular}{|c|c|c|c|}
\hline Gene & Forward/reverse & Primer & UPL probe \\
\hline \multirow[t]{2}{*}{ OTX2 } & Forward & aacctcccatgaggctgtaa & 86 \\
\hline & Reverse & ggtggacaggttcagagtcc & \\
\hline \multirow[t]{2}{*}{ FOXG1 } & Forward & atcagaggcgeccactact & 45 \\
\hline & Reverse & tgtagcaaaagcagcaacca & \\
\hline \multirow[t]{2}{*}{ PLZF } & Forward & caagaagttcagcctcaagca & 78 \\
\hline & Reverse & cactcaaagggettctcacc & \\
\hline \multirow[t]{2}{*}{ MMNR1 } & Forward & gcactatcaagcttgtggaaga & 50 \\
\hline & Reverse & caccatgggtgcatatctgt & \\
\hline \multirow[t]{2}{*}{ GAPDH } & Forward & ctctgctectcctgttcgac & 60 \\
\hline & Reverse & acgaccaaatccgttgactc & \\
\hline \multirow[t]{2}{*}{ GBX2 } & Forward & aaagagggctcgctgctc & 63 \\
\hline & Reverse & atcgctctccagcgagaa & \\
\hline \multirow[t]{2}{*}{ KROX20 } & Forward & ttgaccagatgaacggagtg & 3 \\
\hline & Reverse & tggtttctaggtgcagagacg & \\
\hline \multirow[t]{2}{*}{ АТОH1 } & Forward & ggtggtggtagacgagctg & 11 \\
\hline & Reverse & tctgcaceccattcacct & \\
\hline \multirow[t]{2}{*}{ LHX9 } & Forward & gatgccaaggacctcaagc & 61 \\
\hline & Reverse & ctcgtgcgttttggaacc & \\
\hline \multirow[t]{2}{*}{ MEIS2 } & Forward & gactgatggcgcaaaggta & 43 \\
\hline & Reverse & gaacecctactccgtccatc & \\
\hline \multirow[t]{2}{*}{$S 100 B$} & Forward & ggaaggggtgagacaagga & 78 \\
\hline & Reverse & ggtggaaaacgtcgatgag & \\
\hline \multirow[t]{2}{*}{$B L B P$} & Forward & gaaattaaggatggcaaaatgg & 9 \\
\hline & Reverse & ctcatagtggcgaacagcaa & \\
\hline \multirow[t]{2}{*}{ EN1 } & Forward & gcacacgttattcggatcg & 88 \\
\hline & Reverse & gettgtcctcettctcgttc & \\
\hline \multirow[t]{2}{*}{ EN2 } & Forward & catggcacagggcttgta & 22 \\
\hline & Reverse & tactcgctgtccgacttgc & \\
\hline \multirow[t]{2}{*}{ TUJ1 } & Forward & gcaactacgtgggcgact & 78 \\
\hline & Reverse & cgaggcacgtacttgtgaga & \\
\hline \multirow[t]{2}{*}{ PAX6 } & Forward & ggcacacacacattaacacactt & 9 \\
\hline & Reverse & ggtgtgtgagagcaattctcag & \\
\hline \multirow[t]{2}{*}{$Z I C 2$} & Forward & ccgagaacctcaagatccac & 7 \\
\hline & Reverse & agccctcaaactcacactgg & \\
\hline \multirow[t]{2}{*}{ ZIPRO1 } & Forward & gcggctctgattcatggt & 43 \\
\hline & Reverse & cctcaccaaagatgggactc & \\
\hline \multirow[t]{2}{*}{ GFAP } & Forward & ccaacctgcagattcgaga & 64 \\
\hline & Reverse & tcttgaggtggcettctgac & \\
\hline \multirow[t]{2}{*}{ sox2 } & Forward & tgctgcctctttaagactaggac & 35 \\
\hline & Reverse & cctggggctcaaacttctct & \\
\hline GLI1 & Forward & cagggaggaaagcagactga & 76 \\
\hline & Reverse & actgctgcaggatgactgg & \\
\hline GLI2 & Forward & cacgctctccatgatctctg & 30 \\
\hline & Reverse & cscetctccttaaggtgctc & \\
\hline NMYC & Forward & ccacaaggecctcagtacc & 55 \\
\hline & Reverse & cctcttcatcatcttcatcatctg & \\
\hline CYCLIND1 & Forward & gaagatcgtcgccacctg & 67 \\
\hline & Reverse & gacctcctcctcgcacttct & \\
\hline P21 & Forward & cgaagtcagttccttgtggag & 82 \\
\hline & Reverse & catgggttctgacggacat & \\
\hline$B A X$ & Forward & atgttttctgacggcaacttc & 57 \\
\hline & Reverse & atcagttccggcaccttg & \\
\hline GADD45A & Forward & tttgcaatatgactttggagga & 19 \\
\hline & Reverse & catcccccaccttatccat & \\
\hline
\end{tabular}

tion over the long term ( $>2$ weeks), the medium was switched to N2 media mixed with Neurobasal medium (with $2 \mathrm{~mm}$ L-glutamine, Invitrogen) at ratio of 1:1, with the addition of B27 supplement (1:100, N2B27 medium). The induction of ventral phenotypes was performed by adding sonic hedgehog $(\mathrm{SHH})$ protein $(0.5-1 \mu \mathrm{g} / \mathrm{ml}, \mathrm{R} \& \mathrm{D}$ Systems $)$ to base medium. Induction of dorsal phenotypes was achieved by adding BMP6 (20 ng/ml, R\&D Systems), BMP7 (100 ng/ml, R\&D Systems), or GDF7 (100 $\mathrm{ng} / \mathrm{ml}, \mathrm{R} \& D$ Systems) with WNT3a (20 $\mathrm{ng} / \mathrm{ml}$, R\&D Systems) to base medium. Unpaired Student's $t$ tests were performed to determine whether the fraction of immune-positive cells was significantly different after exposure to $\mathrm{SHH}$ or BMPs/Wnt3a (3 replicate counts). 


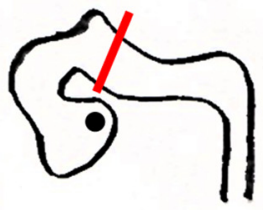

$6 \mathrm{w}$
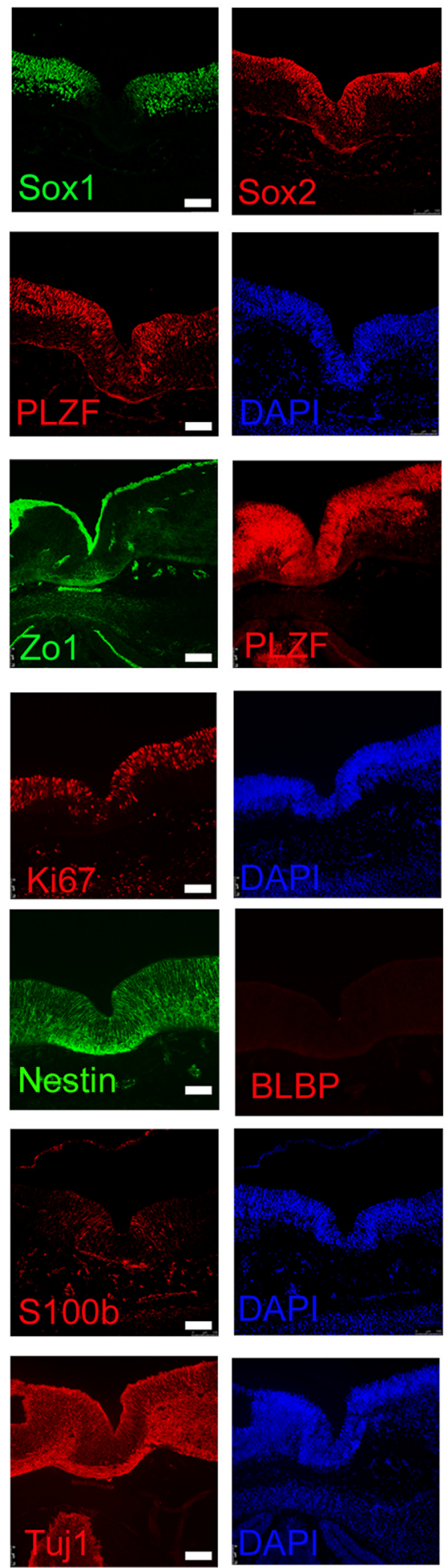
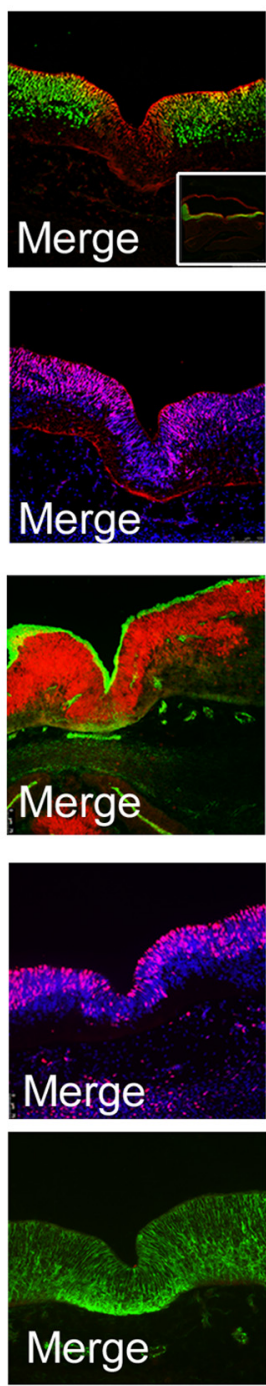

Merge

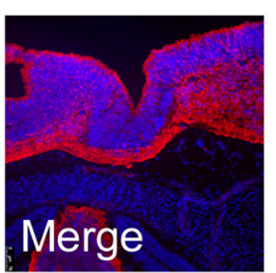

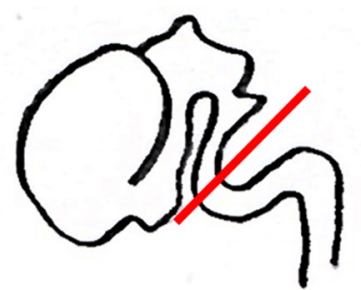

$9 w$
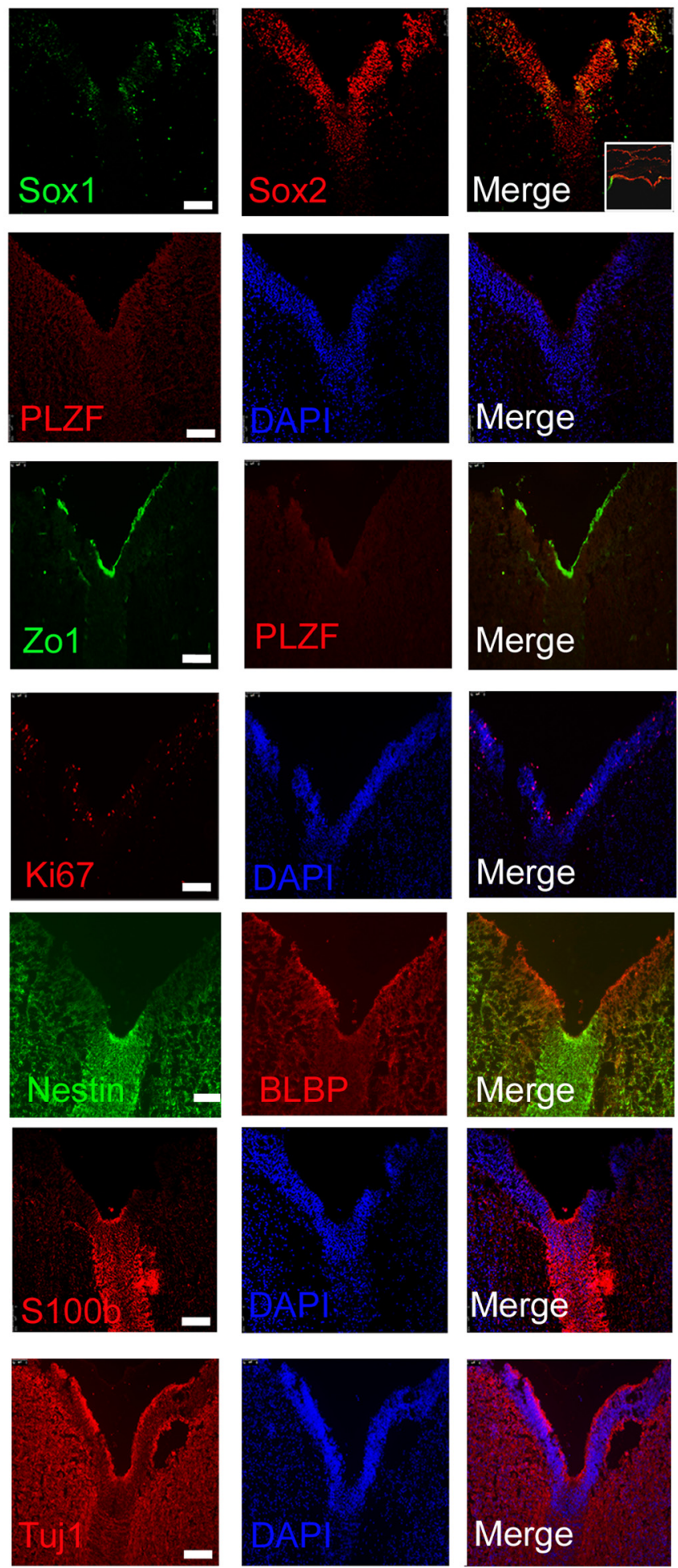
Nucleofection. Plasmids were transfected using the Amaxa or Neon nucleofection kits according to the manufacturer's protocol. For nucleofection with Amaxa, $4 \times 10^{6} \mathrm{NES}$ cells were transfected with $2 \mu \mathrm{g}$ of Piggybac plasmid DNA together with $2 \mu \mathrm{g}$ pBase (transposase) in $100 \mu \mathrm{l}$ of Amaxa buffer. The mixture was added to Amaxa cuvettes before nucleofection using the T20 program (Amaxa). For nucleofection with Neon, $1 \times 10^{6}$ NES cells were transfected with $2 \mu \mathrm{g}$ DNA and $2 \mu \mathrm{g}$ pBase (transposase) in $10 \mu \mathrm{l}$ of resuspension buffer "R." The mixture was collected in $10 \mu$ l pipette tips before nucleofection using program 13 (2 pulses, pulse width 20, voltage 1100). For constitutive GFP expression, a modified piggybac vector (Guo et al., 2009) was used containing a CAG-eGFP-pgk-hph cassette. Expression vector for ATOH1 was generated by modifying a piggybac vector containing pCAG-IRES-hisDdsRED (kindly provided by Masaki Kinoshita). After nucleofection, cells were immediately transferred to prewarmed EF media in one well of a 6-well culture dish. Selection was initiated 3-5 d after transfection using hygromycin at $100 \mu \mathrm{g} / \mathrm{ml}$ (GFP construct) or histidinol at 6 $\mu \mathrm{M}$ (ATOH1 construct).

Isolation of mouse granule cells (GCs) and coculture with GFP-labeled hindbrain neuroepithelial stem ( $h b N E S$ ) cells. The brains of 8-10 P4-P8 mice neonates of either sex were removed, and the cerebella were dissected out in N2 media with penicillin-streptomycin. The meninges were removed, and the cerebella were dissociated into a single-cell suspension with trypsin as previously described (Lu et al., 2004). Briefly, the cerebella were first cut into 7 or 8 smaller pieces, washed twice with PBS, and then incubated with $2.5 \mathrm{ml}$ of trypsin/EDTA and $250 \mu \mathrm{g}$ of DNAase I (QIAGEN) for $10 \mathrm{~min}$. A total of $1 \mathrm{ml}$ of FBS was added to inactivate the trypsin, and the cerebella were allowed to settle at the bottom of the tube before removing the solution. A total of $3 \mathrm{ml}$ of PBS was added to the cerebella and triturated until all the pieces of cerebella disappear. Dissociated cells were then purified on a Percoll step gradient as previously described (Hatten, 1985; Lu et al., 2004). Purified mouse GCs were collected and resuspended in Neurobasal media (Invitrogen) with B27 supplement (1:50, Invitrogen) and penicillin-streptomycin (1:100, Invitrogen) (henceforth called Neurobasal media). hbNES cells labeled with GFP (Sai3 (P20)GFP, passages 5-10) were treated with BMP6, 7 or GDF7 and Wnt3a for $2 \mathrm{~d}$, and subsequently mixed with the mouse GC suspension at a ratio of 1:100. Between 1 and $2 \times 10^{5}$ cells of the GC/hbNES cell mixture were plated into each well of a 12-well plate precoated with poly-L-ornithine and laminin in Neurobasal medium. Medium was changed every $2-3 \mathrm{~d}$ for up to 3 months.

Figure 1. Neuroepithelial markers SOX1, SOX2, and PLZF are expressed in the anterior hindbrain neuroepithelium at 6 weeks gestation. $50 \mathrm{X} 1$ and $\mathrm{SO} 2 \mathrm{2}$ are both expressed in the Carnegie $15-16, \sim 6$ week $(6 \mathrm{w})$ hindbrain neuroepithelium, but $S 0 X 1$ is excluded from the midline. SOX1 is sparse and limited to the dorsolateral neuroepithelium at Carnegie $23, \sim 9$ week gestation (9w) (low power; insets, $\times 5$ ). PLZF expression is similar to S0X1 in the $6 \mathrm{w}$ hindbrain neuroepithelium and likewise decreases at $9 w$. 20-1 is localized to the apical side of the neuroepithelium at both $6 w$ and $9 w$ of development. Nestin is also expressed in the neuroepithelium and hindbrain proper at both stages. Ki67 expression is found in a greater proportion of cells in the $6 w$ hindbrain compared with $9 w$. $5100 \beta$ expression in the $6 w$ hindbrain neuroepithelium is weaker compared with $9 \mathrm{w}$, especially in the most ventral region. BLBP was absent in the $6 \mathrm{w}$ hindbrain neuroepithelium. Tuj1-expressing neurons are found in the $6 \mathrm{w}$ hindbrain; however, the hindbrain proper is much thicker and contains a greater number of Tuj1-expressing neurons at 9 w. Sections are from the same embryos (all pictures, original magnification $\times 20$ ). Scale bar (first panel of each image), $100 \mu \mathrm{m}$ ).
B
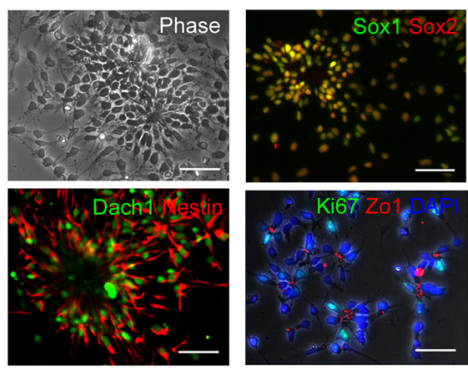

D

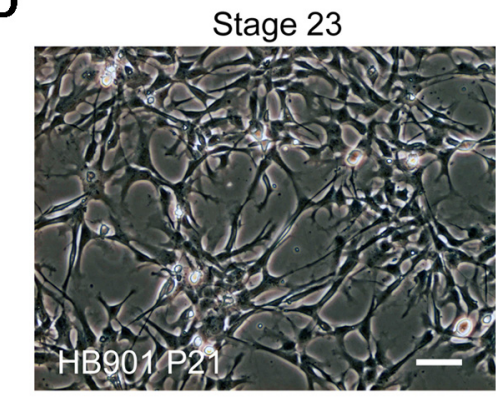

Stage 15

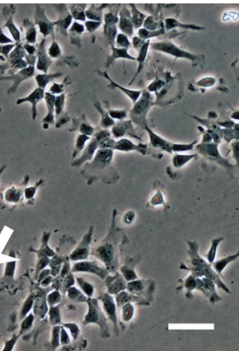

Figure 2. Rosette-forming cells can be isolated and expanded from human embryos. $\boldsymbol{A}$, The central nervous system regions of a (week 7) embryo is shown: f, Forebrain; m, midbrain; h, hindbrain; MHB, midbrain-hindbrain boundary; 4v, fourth hindbrain tissue do not form rosettes (HB901, passage P21). Scale bars: $\boldsymbol{A}, 1 \mathrm{~mm} ; \boldsymbol{B}, 50 \mu \mathrm{m} ; \boldsymbol{C}, \boldsymbol{D}, 100 \mu \mathrm{m}$. Multiple embryos were dissected at each stage (Table 2); the images are from representative stage embryos.

Table 2. Summary of cell lines derived from Carnegie stage 15-23 (week 5-9) embryonic hindbrain

\begin{tabular}{|c|c|c|c|c|c|}
\hline Reference & $\begin{array}{l}\text { Carnegie } \\
\text { stage }\end{array}$ & $\begin{array}{l}\text { Primary } \\
\text { cells died }\end{array}$ & $\begin{array}{l}\text { NES or NS-like } \\
\text { after }>5 \text { passages }\end{array}$ & $\begin{array}{l}\text { NES } \\
\text { cell line }\end{array}$ & $\begin{array}{l}\text { No. of passages } \\
\text { to date }\end{array}$ \\
\hline 802 & 15 & - & NES & SAl1 & $55-60$ \\
\hline 877 & 15 & - & NES & HB877 & $10-15$ \\
\hline 895 & 15 & - & NES & SAI3 & $45-50$ \\
\hline 896 & 15 & - & NES & SAI4 & $30-35$ \\
\hline 819 & 16 & Yes & - & - & - \\
\hline 824 & 16 & Yes & - & - & - \\
\hline 843 & 16 & - & NES & SAI2 & $45-50$ \\
\hline 883 & 17 & Yes & - & - & - \\
\hline 887 & 17 & - & NES & HB887 & $10-15$ \\
\hline 897 & 17 & - & NES & SAI5 & $25-30$ \\
\hline 886 & 18 & Yes & - & - & - \\
\hline 930 & 19 & - & NS & HB930 & $20-25$ \\
\hline 804 & 20 & - & NS & HB804 & $5-10$ \\
\hline 855 & 20 & Yes & - & - & - \\
\hline 879 & 21 & Yes & - & - & - \\
\hline 847 & 23 & - & NS & HB847 & $5-10$ \\
\hline 901 & $23+$ & - & NS & HB901 & $30-35$ \\
\hline 985 & $23+$ & - & NS & HB985 & $15-20$ \\
\hline
\end{tabular}

-, Not applicable.

Derivation of clonal lines. Clonal lines were derived by single-cell deposition of hbNES cells into 96-well plates coated with human fibroblast (HS27) feeders using a flow cytometer (Moflo, Dako). Medium was changed every $2-3 \mathrm{~d}$. After 2 weeks, colonies were observed in $\sim 10-20 \%$ of the wells. The colonies were trypsinized and transferred individually to a 48-well plate coated with poly-ornithine and laminin without feeders for further expansion.

Growth kinetics. Images were captured every $15 \mathrm{~min}$ using the Incucyte system (Essen Instruments), and growth quantified by the increase in area occupied by cells (supplemental movie, see Notes). 


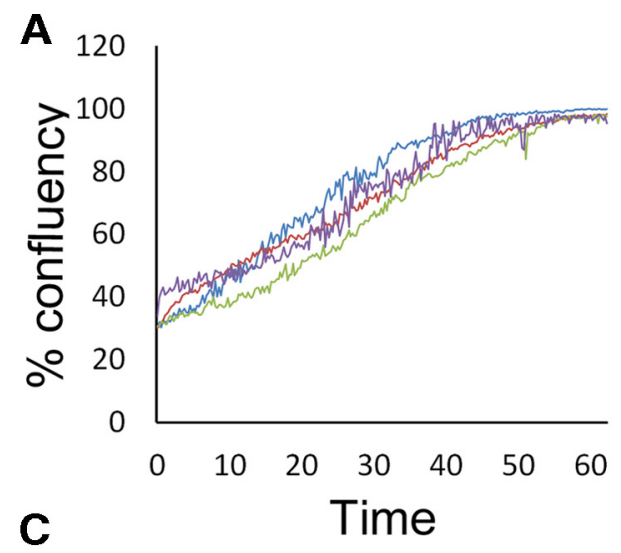

\section{B}

- Sai1 P30

Sai1 P51

-Sai1 clone
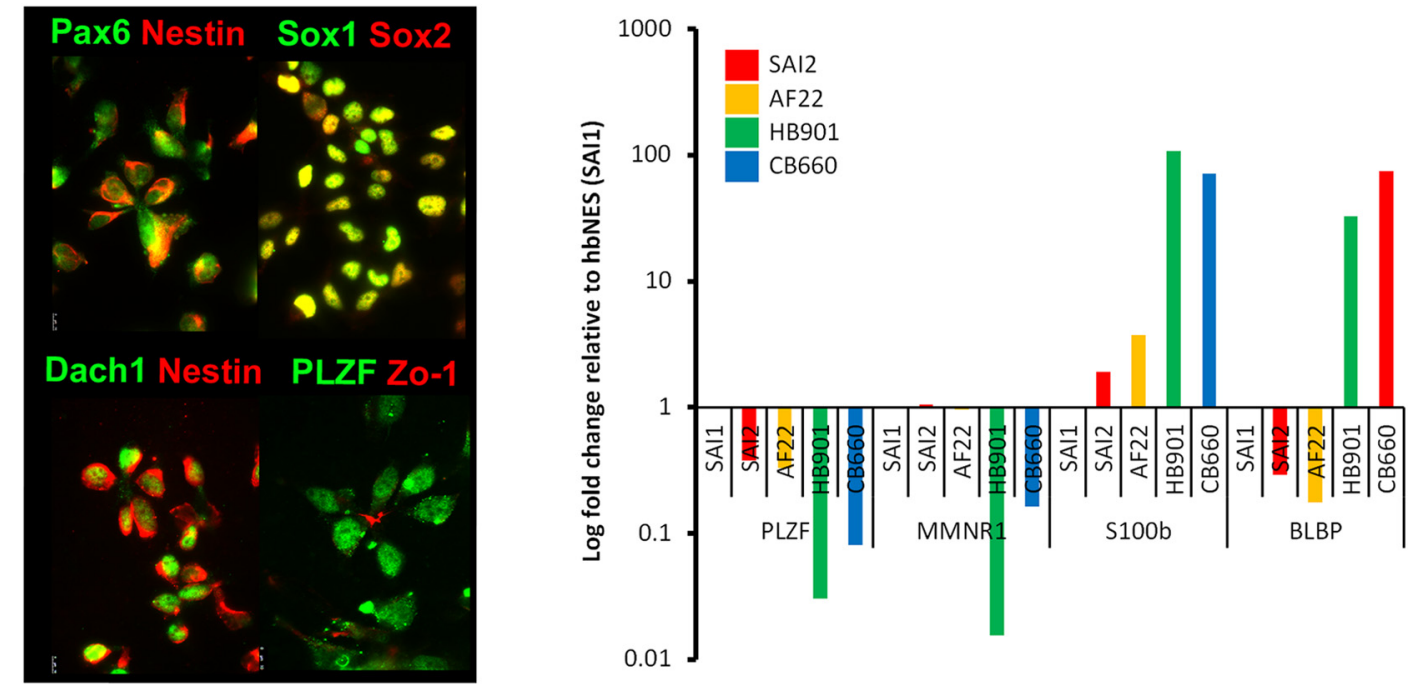

E

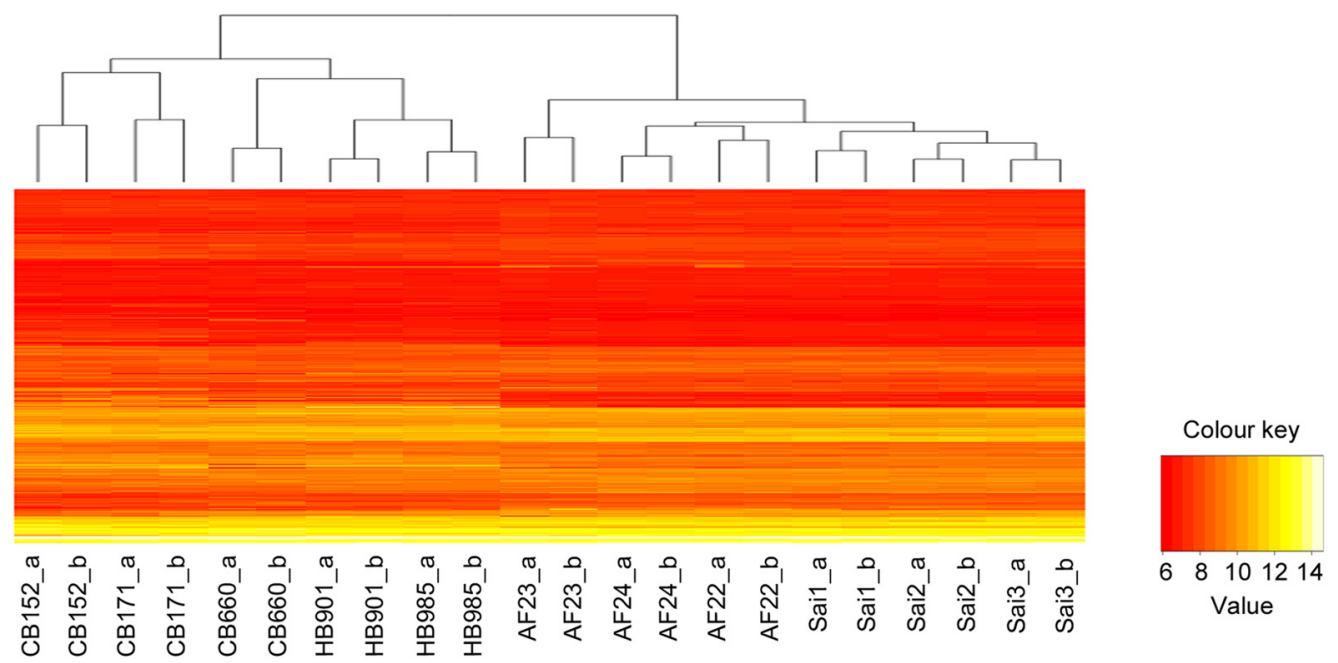

Figure 3. hbNES cells maintain stable growth properties and express neuroepithelial markers. $A$, The growth rate of hbNES cells (Sai1) was examined by live video microscopy. The percentage confluence is plotted against time. Sai1 cells displayed a doubling time of $\sim 24 \mathrm{~h}$, similar to pluripotent-derived It-NES cells (AF22, passage 20). This growth pattern is consistent at 30 and 51 passages and in a clonal derivative. B, Normal karyotype of hbNES cells (Sai1) after 51 passages. C, hbNES cells (Sai1) express early pan-neural (SOX1, SOX2, PAX6, and Nestin) markers and genes enriched in pluripotent stem cell-derived neural rosettes (PLZF and Dach1). The cells demonstrate a tendency to form rosette-like structures with Z0-1 at the apical junction. D, qRT-PCR analysis of rosette markers (PLZFand MMNR1) and radial glia markers (S100 $\beta$ and BLBP) in hbNES cells (Sai1 and Sai2), It-NES cells (AF22), hindbrain NS-like cells (HB901), and forebrain NS cells (CB660). mRNA expression level (3 replicates/cell line) is relative to GAPDH and normalized to Sai1 cell line. PLZF and DACH1 are expressed in hbNES cells, but S100 $\beta$ and BLBP are not. $\boldsymbol{E}$, Heat map of whole-genome expression analyzed with Illumina bead chip microarrays. hbNES cells (Sai1, Sai2, and Sai3) cluster together with iPS cell-derived NES cells (AF22, AF23, and AF24) and separate from hindbrain NS-like cells derived from older fetuses (HB901 and HB985), or forebrain NS cells (CB660, CB171, and CB152). The duplicate samples are denoted as "_a" and "_b."

Cryosectioning. Carnegie stage 15-16 (6 week) and stage 23 ( 9 week) embryos (one each) were fixed in $4 \%$ PFA for $12 \mathrm{~h}$ at $4^{\circ} \mathrm{C}$ and incubated in $15 \%$ sucrose solution at $4^{\circ} \mathrm{C}$ overnight. The fetuses were then immersed in $7.5 \%$ gelatin- $15 \%$ sucrose solution overnight at $37^{\circ} \mathrm{C}$.
The next day, the fetuses were embedded in plastic cryomoulds with $7.5 \%$ gelatin- $15 \%$ sucrose that was preheated at $37^{\circ} \mathrm{C}$, cooled on ice until the gelatin solution solidified around the fetus in the correct orientation, and then frozen on dry ice. Frozen blocks were stored at 
$-80^{\circ} \mathrm{C}$ until ready for cryosectioning. Sections were cut onto glass slides (Super) at $-20^{\circ} \mathrm{C}$ at a thickness of $10-15 \mu \mathrm{m}$.

Immunofluorescence. Cells were fixed with 4\% PFA for $10 \mathrm{~min}$ and then washed with PBS solution. Blocking solution made up of $0.3 \%$ Triton X-100 and 5\% goat or donkey serum in PBS was applied to the cells for $1 \mathrm{~h}$ in room temperature followed by the primary antibody (in PBS with $0.1 \%$ Triton X-100 and $1 \%$ BSA) for $12 \mathrm{~h}$ at $4^{\circ} \mathrm{C}$. The source and dilutions of primary antibodies were as follows: anti-Tuj1 (R\&D Systems, 1:200; Covance, 1:500), antiGABA (Sigma, 1:1000), anti-5-HT (Sigma, 1:1000), anti-GFAP (Sigma, 1:200; R\&D Systems, 1:50), anti-NeuN (Millipore Bioscience Research Reagents, 1:100), anti-O4 (R\&D Systems, 1:100), anti-vglut1 (Synaptic Systems, 1:3000), antivglut2 (Synaptic Systems, 1:3000), anti-Ki67 (Thermo Scientific, 1:200), anti-Sox1 (Cell Signaling Technology, 1:200), anti-Sox2 (R\&D Systems, 1:50), anti-Pax6 (Covance, 1:400), antiNestin (R\&D Systems, 1:200), anti-PLZF (Calbiochem, 1:50), anti-Dach1 (Proteintech, 1:100), anti-ZO-1 (Zymed, 1:100), anti-islet-1 (DSHB, 1:20), anti-Lim1/2 (DSHB, 1:20), anti-Lim3 (DSHB, 1:20), anti-Nkx6.1 (DSHB, 1:20), antiNkx2.2 (DSHB, 1:20), anti-Msx1/2 (DSHB, 1:20), anti-Pax3 (DSHB, 1:10), anti-S100 $\beta$ (Sigma, 1:2000), anti-BLBP (Santa Cruz Biotechnology, 1:100), anti-Pde1c (Abcam, 1:100), antiEn2 (R\&D Systems, 1:50), anti-Atoh1 (Proteintech, 1:1000), anti-Zicl (gift from R. Segal, 1:500), anti-Zic2 (Millipore, 1:500), antiKrox20 (gift from J. Ericsson, 1:1000), antisynaptophysin (Abcam, 1:250), anti-human NCAM (Santa Cruz Biotechnology, 1:100), antihuman nuclei (Millipore, 1:1000), anti-calretinin (Santa Cruz Biotechnology, 1:100), antidoublecortin (Cell Signaling, 1:200), and antiGABRA $\alpha 6$ (Millipore, 1:1000). Primary antibody was then removed and the cells washed twice with PBS before adding secondary antibody solution with DAPI for $45 \mathrm{~min}$ to $1 \mathrm{~h}$. Specificity of staining was determined by staining cells with secondary antibody solution with DAPI only. Cells were visualized using an inverted fluorescent microscope (Leica DMI 4000, original magnification $\times 20-63$ ) and images captured using LASAF (Leica Application Suite Advanced Fluorescence). Images were taken from at least three random places in each well, and at least two separate wells were analyzed in each experiment. Cryosection slides were incubated in PBS for $30 \mathrm{~min}$ at $37^{\circ} \mathrm{C}$ before immunostaining and subsequently treated with blocking and antibody solutions as described above.

$R N A$ preparation, $q R T-P C R$, and microarray analysis. Total RNA was extracted with RNAeasy (QIAGEN) kit. The RNA concentration was determined with Nanodrop-1000 (Thermo Scientific). Superscript III (Invitrogen) was used to synthesize cDNA from $1 \mu \mathrm{g}$ of total RNA. Relevant genes were amplified us-

ing TaqMan fast universal PCR mastermix (Applied Biosystems), Universal Probe Library (Roche) probes and primers (Table 1). At least two technical replicates were performed for each biological sample.

Alternatively, the cDNA was loaded onto a custom-designed 192-gene TaqMan Low Density Array card, and technical duplicates were assayed using a 7900HT real-time PCR machine (Applied Biosystems). qRT-PCR
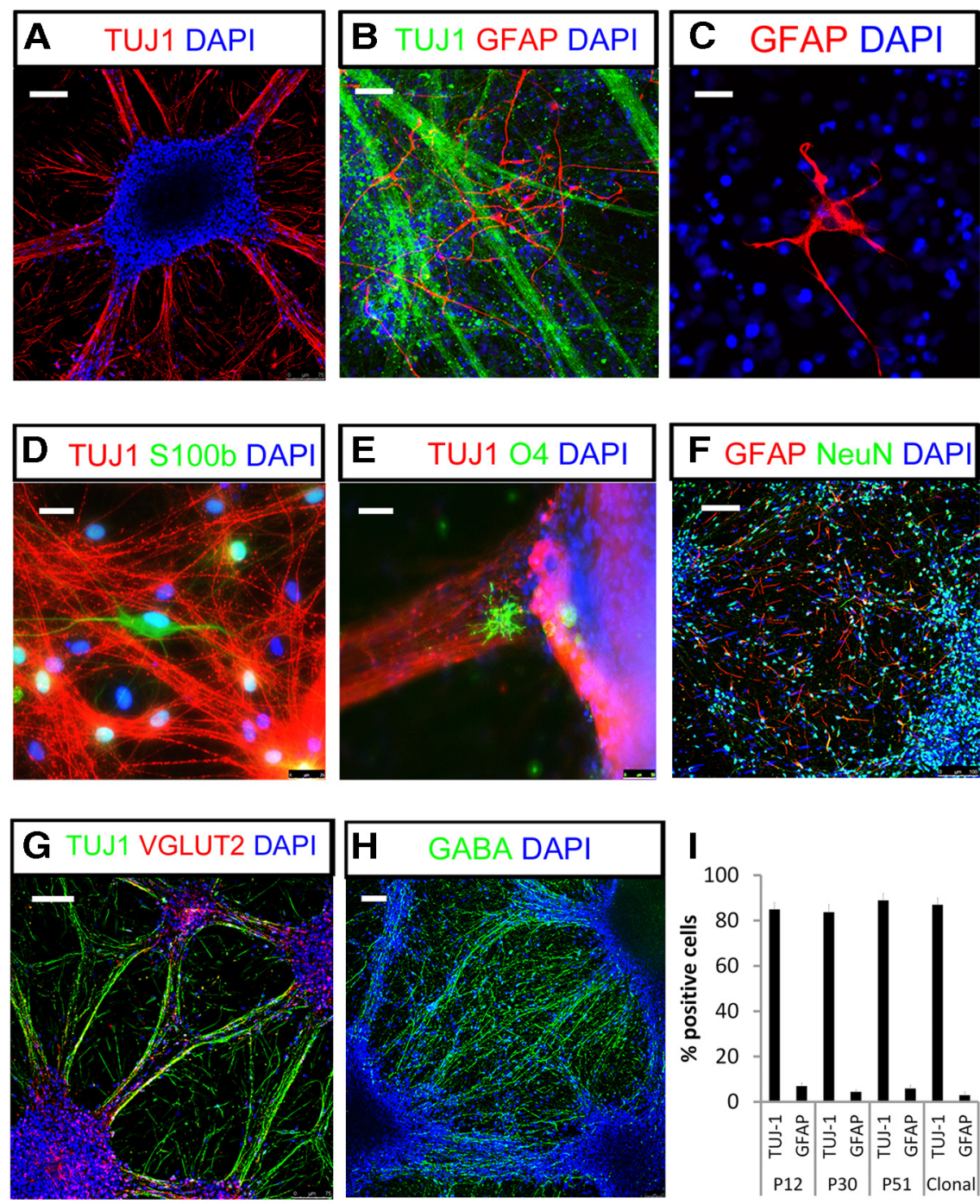

$J$

2-3 months
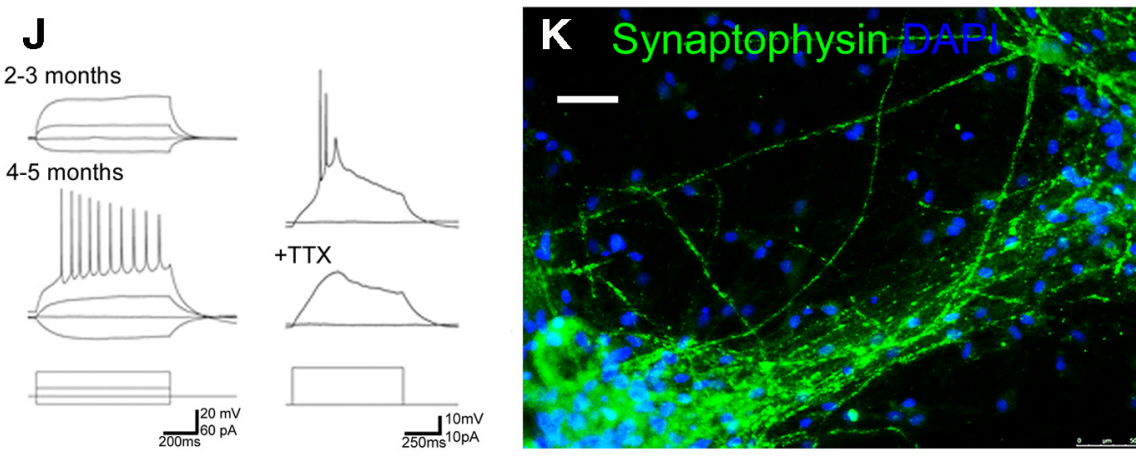

Figure 4. hbNES cells maintain neurogenic potency after long-term culture. hbNES cells are multipotent and differentiate into Tuj1 $(\boldsymbol{A}, \boldsymbol{B}, \boldsymbol{D}, \boldsymbol{E}, \boldsymbol{G}), \operatorname{NeuN}(\boldsymbol{F})$, vGLUT2 $(\boldsymbol{G})$, and GABA $(\boldsymbol{H})$ positive neurons, as well as GFAP $(\boldsymbol{B}, \boldsymbol{C}, \boldsymbol{F})$ and $\mathrm{S} 100 \beta(\boldsymbol{D})$ positive astroglial cells, and rare $04(\boldsymbol{E})$ positive oligodendrocyte lineage cells. In the absence of added extrinsic factors, differentiation appears biased toward neurogenesis, with $>80 \%$ of cells staining positive for Tuj1 after $14 \mathrm{~d}$. Neurogenic potency is maintained over long-term expansion $(I)$. After $\sim 4$ months of differentiation in culture, hbNES cell-derived neurons show features consistent with functional maturation in vitro, including TTX-responsive action potentials $(\boldsymbol{J})$ and synaptophysin-expressing axonal projections $(\boldsymbol{K})$. Scale bars: $\boldsymbol{C}-\boldsymbol{E}, 20 \mu \mathrm{m} ; \boldsymbol{K}, 50 \mu \mathrm{m} ; \boldsymbol{A}, \boldsymbol{B}, \boldsymbol{G}, 75 \mu \mathrm{m} ; \boldsymbol{F}, \boldsymbol{H}, 100 \mu \mathrm{m}$.

data from the TaqMan Low Density Array card was analyzed using StatMiner software (Integromics).

Whole-genome expression analysis on NES (Sai1, Sai2, Sai3, AF22, AF23, and AF24) and NS (HB901, HB985, CB660, CD171, and CB152) cell lines was performed using the Illumina bead chip array. Duplicate samples were analyzed for each cell lines (denoted as "_a" and "_b"). Nonexpressed probes with a detection $p>0.01$ in all samples were re- 
moved. Data were transformed by variance stabilization transformation using the lumi Bioconductor package, and the data were quantile normalized between arrays. Clustering analysis was performed with the $\mathrm{R}$ hclust function using complete linkage clustering and Pearson correlation as a distance measure.

Metaphase chromosome analysis. Colcemid (Invitrogen, 15210-057) was added to $\sim 50 \%$ confluent cultures of hbNES cells at a final working concentration of $0.1 \mu \mathrm{g} / \mathrm{ml}$ for $2 \mathrm{~h}$. Cells were then trypsinized and centrifuged in N2 media for $3 \mathrm{~min}(300 \times g)$, and resuspended by flicking the tube. A total of $5 \mathrm{ml}$ of hypotonic $\mathrm{KCl}$ solution $(0.055 \mathrm{M})$ was then added to the pellet, gently mixed by inverting the tube twice, and centrifuged. The supernatant was removed the cells were fixed by gently added $3 \mathrm{ml}$ of 3:1 methanol/acetic acid. The cells were centrifuged again, resuspended in this fixative, and stored at -20 degrees. Metaphase spreads were prepared using standard methods. Cytogenetic analysis was conducted at the Medical Genetics Laboratories (Cambridge Biomedical Campus) on metaphase cells (passages 30 and 50) using G-banding on a minimum of 10 cells per sample.

Electrophysiological recordings. Somatic whole-cell patch-clamp recordings were made from hbNES cell-derived neurons after 2-5 months of differentiation. Individual coverslips were placed in the recording chamber perfused at a flow-rate of $\sim 3.5 \mathrm{ml} / \mathrm{min}$ with artificial CSF (aCSF) as follows: $126 \mathrm{~mm} \mathrm{NaCl}, 10 \mathrm{~mm}$ glucose, $3 \mathrm{~mm} \mathrm{KCl}, 2 \mathrm{~mm} \mathrm{MgSO}_{4}, 1.25 \mathrm{~mm} \mathrm{NaH}_{2} \mathrm{PO}_{4}$, $2 \mathrm{mM} \mathrm{CaCl}_{2}$, and $26.4 \mathrm{~mm} \mathrm{NaHCO} 3$ (bubbled with $95 \% \mathrm{O}_{2}, 5 \% \mathrm{CO}_{2}$ ), at room temperature. For some experiments, the voltage-gated sodium channel blocker TTX ( $1 \mathrm{~mm}$; Alomone Laboratories) was added to the perfusion system. Patch pipettes (1B120F-4, World Precision Instrument) were pulled using a horizontal micropipette puller (Sutter Instruments) and filled with a solution containing the following: $110 \mathrm{~mm}$ potassium gluconate, 40 mM HEPES, 4 mM NaCl, 4 mm ATP-Mg, 0.3 mм GTP; $p H$ adjusted to 7.2 with $\mathrm{KOH}$. Once filled, the tip resistance was between 4 and $5 \mathrm{M} \Omega$. Currentclamp recordings were performed with a Multiclamp 700B amplifier (Molecular Devices). Signals were filtered at $6 \mathrm{kHz}$ and digitized at $8 \mathrm{kHz}$ (Instrutech ITC-18). Customized procedures within Igor Pro software (version 6.12A, WaveMetrics) were used to generate command signals and to collect and analyze data.

Neonatal transplantation. Postnatal day 1-3 Sprague Dawley rats of either sex were anesthetized with isoflurane and oxygen and were kept warm on a heat pad throughout the procedure. A small vertical incision was made aseptically to the skin over the back of the head, the $\lambda$ identified, and a small window made in the occipital bone $\sim 0.5 \mathrm{~cm}$ below the lambdoid suture. A cell suspension of hbNES cells (Sai1, Sai3, and Sai3-GFP) was prepared in $\mathrm{N} 2$ media at a concentration of 50,000 cells/ $\mu$ l and loaded into a fine glass capillary tube using a Nanoject II microinjector kit (Drummond Scientific). The dura was pierced with the glass capillary tube, and $1 \mu$ l of cell suspension was injected just under the dura. The skin was closed with GLUture (Abbott Laboratories), and the neonates were recovered on a heat pad with dry bedding and oxygen, before being returned to the mother.

In utero transplantation. In utero transplants of hbNES cells (Sai1, Sai3, and Sai3-GFP) in mice and rats were performed as previously described (Cattaneo et al., 1994; Carletti et al., 2002; Williams et al., 2008). Briefly, timed-pregnant E13-E15 rats or mice of either sex were anesthetized with isoflurane and oxygen, and the uterine horns were exposed. The embryonic CNS was identified under transillumination, and 1-2 $\mu$ l of the cell suspension (50,000 cells) was gently injected into the fourth ventricle by means of a glass capillary inserted through the uterine wall. The embryos were placed back into the abdomen for spontaneous delivery. Live-born recipient rats were perfused and examined at different postnatal ages $(\mathrm{P} 7, N=10 ; \mathrm{P} 30$, $N=15)$.

\section{Results}

\section{Marker expression profile in the early human hindbrain}

We first investigated the expression in the human hindbrain of early pan-neural transcription factors, SOX1 and SOX2, and of markers PLZF and ZO- 1 characteristic of rosette cells (Elkabetz et al., 2008) and lt-NES cells (Koch et al., 2009). As expected, SOX2 was detected in nuclei throughout the hindbrain neuroepithelium and ZO-1 was localized to the apical (ventricular) mem-
Table 3. Electrophysiological properties of neurons after 2-3 months and 4-5 months differentiation in vitro ${ }^{a}$

\begin{tabular}{lcc}
\hline & $2-3$ months & $4-5$ months \\
\hline Proportion of neuron-like cells & $10 / 14$ & $21 / 24$ \\
RMP $(\mathrm{mV})$ & $-27.9 \pm 6.1$ & $-38.9 \pm 3.9$ \\
$\operatorname{Rin}(\mathrm{M} \Omega)$ & $1701 \pm 511$ & $1047 \pm 249$ \\
$\tau(\mathrm{ms})$ & $59.3 \pm 13.9$ & $62.2 \pm 10.6$ \\
Proportion of spiking cells & $2 / 10$ & $7 / 21$ \\
Threshold (mV) & $-16.8 \pm 1.2$ & $-24.6 \pm 2.7$ \\
Amplitude $(\mathrm{mV})$ & $36.2 \pm 4.0$ & $47.0 \pm 8.0$ \\
Width (ms) & $4.9 \pm 2.5$ & $3.8 \pm 1.1$ \\
\hline
\end{tabular}

${ }^{a}$ The electrophysiological properties of cultured cells at two different differentiation times (2-3 months, $n=24$; $4-5$ months, $n=14$ ) were investigated using whole-cell recordings. The analysis of passive properties of the cell membrane identified two cell types: a glial group with low input resistance and membrane time constant (2-3 months, $n=4 ; 4-5$ months, $n=3$ ) and a neuronal group ( $2-3$ months, $n=10 ; 4-5$ months, $n=21$ ). The resting membrane potential (RMP) of neuron-like cells from both populations was weakly polarized (2-3 months, $-27.9 \pm 6.1 \mathrm{mV} ; 4-5$ months, $-38.9 \pm 3.9 \mathrm{mV}$ ). The proportion of neuron-like cells firing action potentials increased over differentiation time ( $2-3$ months, $20 \% ; 4-5$ months, $33 \%$ ). Moreover, action potentials of hindbrain NES cell-derived neurons maturated over time because their amplitude was increased and more reliable.

Rin, Inward resistance; $\tau$, time constant.

brane in all specimens examined (Fig. 1). In contrast, SOX1 and PLZF were prominent in Carnegie stage 15-16 ( 5-6 week) human embryo hindbrain but were downregulated and limited to posterior (data not shown) and dorsolateral regions in slightly older (Carnegie stage 22-23, 8-9 week) embryos (Fig. 1). Consistent with studies in rodents (Pevny et al., 1998), SOX1 was absent in the most ventral domain of the hindbrain neural tube. Notably, the proliferation marker Ki67 followed a similar pattern to SOX1 and PLZF (Fig. 1). Conversely, the radial glia marker BLBP was absent in the 5-6 week neuroepithelium but was readily detected in 8-9 week hindbrain (Fig. 1). The astroglial marker S100 $\beta$ was also sparse in 5-6 week neuroepithelium but strongly expressed at 8-9 weeks, especially in the most ventral region (Fig. $1)$. The differentiation marker TuJ1 was already present within the 5-6 week hindbrain proper in cells emerging from the neuroepithelium, but a much larger population of TuJ1-positive cells was evident in older specimens (Fig. 1). Nestin was expressed in the neuroepithelium and hindbrain proper in all specimens.

These observations suggest that SOX1 and PLZF-positive cells in the 5-6 week neuroepithelium are actively proliferating, although neurogenesis has already begun in the hindbrain at this stage. They also point to a transition in the hindbrain neuroepithelium between weeks 5-6 and 8-9 of development. During this period, cells downregulate genes associated with early neuroepithelial identity and become less proliferative.

\section{Derivation of cell lines from embryonic hindbrain}

We dissected the anterior hindbrain from available specimens at different developmental stages. The anterior hindbrain was demarcated as the region immediately caudal to the midbrain-hindbrain boundary (Fig. 2A). We plated dissociated cells on poly-L-ornithine/ laminin-coated plates to observe the morphology and behavior of the neural progenitors. Remarkably, in cultures from the 5-6 week hindbrain, rosette formations developed within $12 \mathrm{~h}$ (Fig. 2B). They expressed pan-neural markers SOX1, SOX2, and Nestin, the neuralrosette stage marker Dach1, and the proliferation marker Ki67, and exhibited polar localization of ZO-1 (Fig. $2 B$ ). In contrast, hindbrain tissue from older fetuses rarely generated rosettes in culture and typically exhibited higher levels of neuronal differentiation and cell death.

We found that early hindbrain neuroepithelial cells proliferated in the presence of EGF and FGF2 in identical medium used to culture pluripotent stem cell-derived lt-NES cells (Falk et al., 2012). The initial heterogeneous cultures could be passaged within $3 \mathrm{~d}$ using 


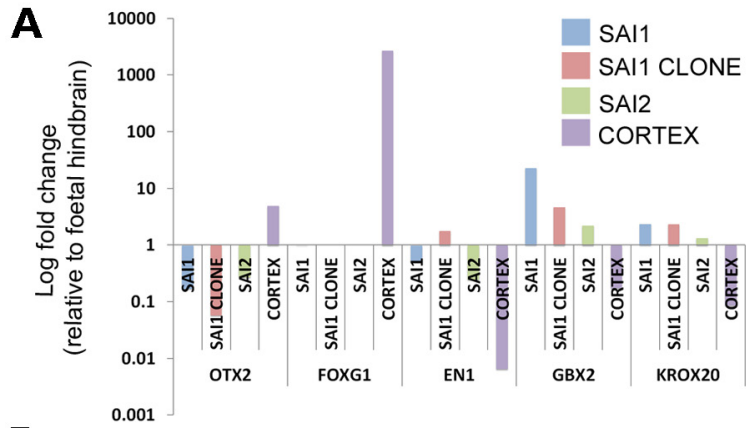

D (i) Microarray

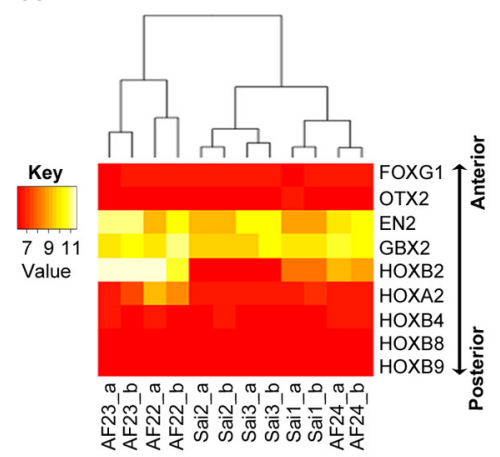

$\mathbf{F}$

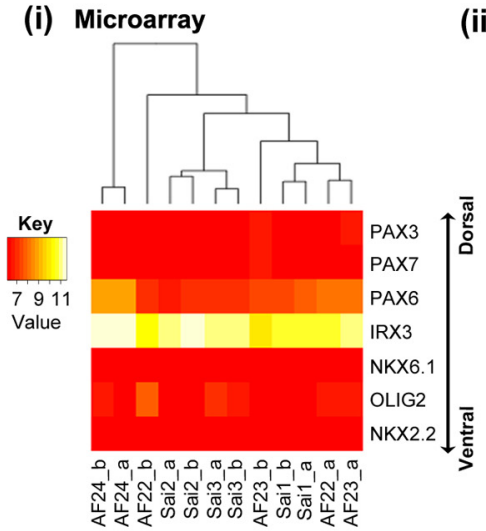

(ii) qRT-PCR
B

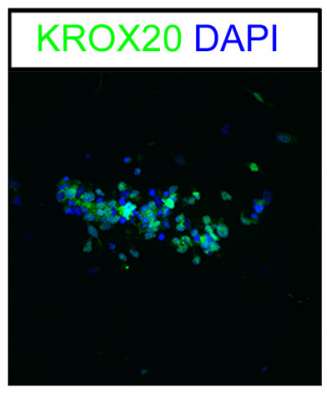

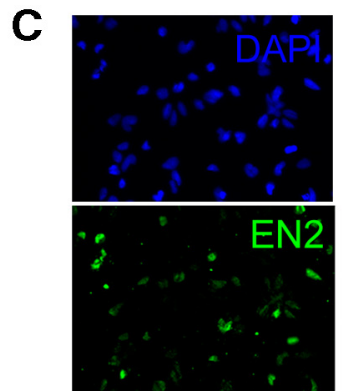

E
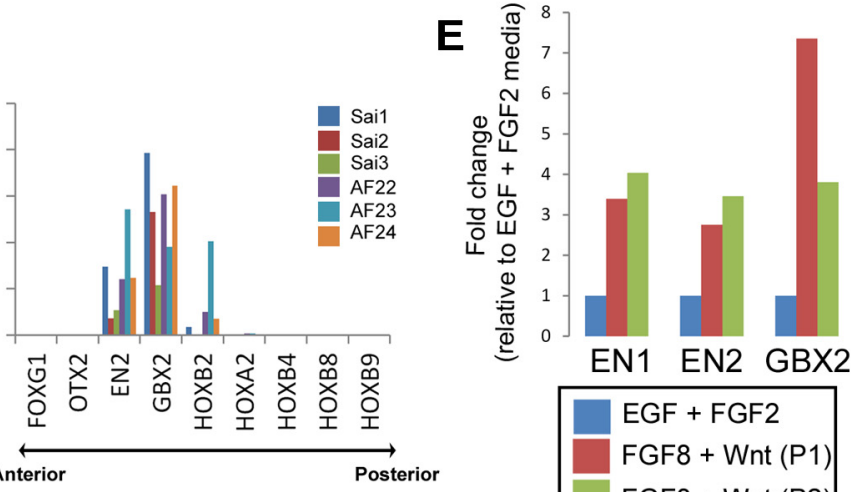

\section{Anterior}

Posterior

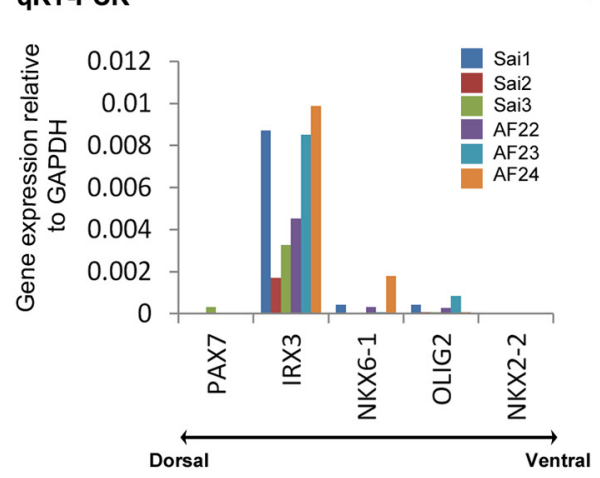

G

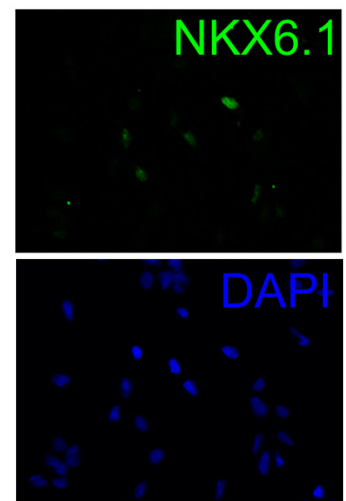

H

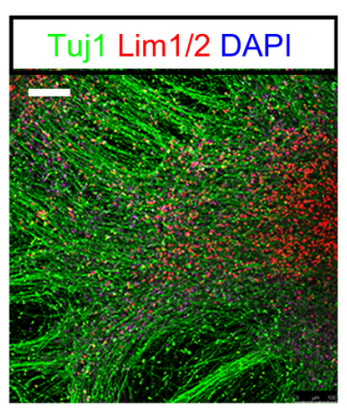

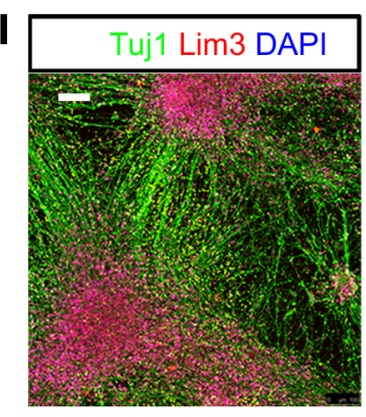
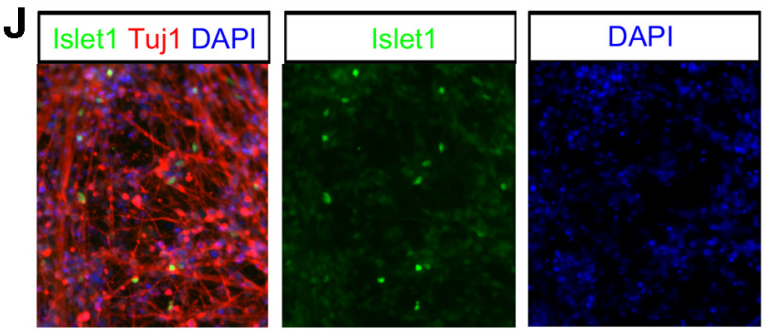

$\mathbf{K}$

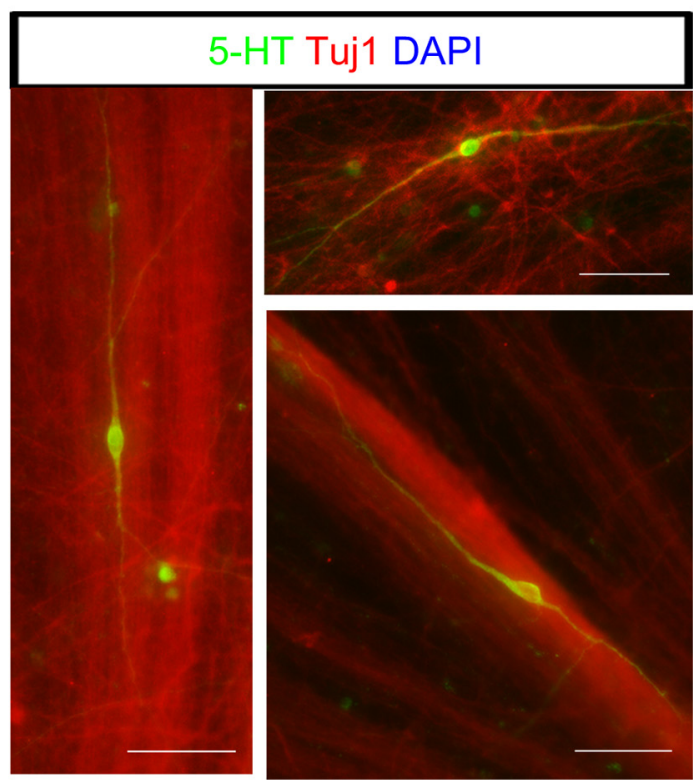

Figure 5. hbNES cells retain anterior hindbrain identity after long-term culture. A, qRT-PCR analysis of hbNES cell lines (Sai1 and Sai2, passage P25-P30) shows expression of EN1, GBX2, and KROX20 at levels that are comparable with primary anterior hindbrain from week 5- 6 human embryos (hindbrain), even at the clonal level (Sai1 clone, passage 10). Anterior markers 0TX2 and FOXG1 are not expressed in hbNES cells (primary cortex from 5 or 6 human embryos was used as positive control). B, KROX20 immunostaining of Sai2 cells. C, EN2 (Figure legend continues.) 
trypsin, after which a more uniform monolayer emerged. Cell death was minimal when cell density was high $\left(4-5 \times 10^{4}\right.$ cells $\left./ \mathrm{cm}^{2}\right)$. Medium was partially renewed every $2-3 \mathrm{~d}$ to allow for culture conditioning during initial establishment of propagating cultures. In this way, we derived stable cell lines of similar morphology from Carnegie stage $15-18$ hindbrains in 7 of 11 attempts (63\%) (Table 2). These cultures were characterized by the continuous production of rosettes over repeated passages (Fig. 2C). Individual cells had a high nuclear to cytoplasmic ratio and displayed a mermaid-like tail (Fig. $2 C$, white arrows). By video microscopy, we noted that the cells tended to divide at the apical end of the plasma membrane where they converge at the center of the rosette. This is reminiscent of the behavior of neuroepithelial progenitors, which divide at the ventricular surface membrane (Götz and Huttner, 2005).

Cells from hindbrain older than Carnegie 18 could also be passaged in EGF and FGF2 (3 of 7 attempts, 43\%) (Table 2). However, they did not form rosettes and morphologically resembled radial glia-like NS cells, similar to those previously derived from $\sim 8$ week human cortex and spinal cord (Sun et al., 2008) (Fig. 2D).

\section{Characterization of hindbrain neuroepithelial stem cells}

Hindbrain neuroepithelial stem (hbNES) cell lines had a doubling rate of $\sim 24 \mathrm{~h}$ (Fig. $3 A$ ). They retained proliferation for $>50$ passages with no evidence of chromosomal instability in three independent cell lines (Sai1, Sai2, and Sai3) (Fig. 3B). hbNES cells were optimally maintained at a plating density of 20,000-30,000 cells $/ \mathrm{cm}^{2}$, which allowed cell to cell contact. Cells typically juxtaposed and self-organized into rosette-like structures (Fig. 2C; supplemental movie, see Notes). Cells survived poorly at singlecell density on poly-L-ornithine/laminin. However, clones could be derived by plating individual cells on human fibroblast (HS27) feeders. After initial colony formation, clones could be expanded and maintained without feeders.

The hbNES cells exhibited a relatively homogeneous expression of SOX1, SOX2, and Nestin (Fig. 3C). More than $80 \%$ of cells expressed PAX6, and most cells expressed neural rosette markers PLZF and Dach1. The apical polarity protein ZO-1 was localized at the junction of rosette-like structures, consistent with apicalbasal polarity (Fig. 3C). At the transcript level, rosette markers $P L Z F$ and MMNR1 were readily detected in hbNES cells, whereas expression of $S 100 \beta$ and $B L B P$ was low in contrast to more mature NS-like cells derived from older fetal hindbrain (HB901) and to forebrain NS cells (CB660) (Fig. 3D). BLBP was not detected in hbNES cell lines by immunostaining (data not shown). We then examined whole-genome mRNA expression using Illumina array technology. hbNES cells (Sai1, Sai2, and Sai3) clustered together and with iPS cell-derived lt-NES cells (AF22, AF23, and AF24), but apart from hindbrain derived NS-like cells (HB901 and

\section{$\leftarrow$}

(Figure legend continued.) immunostaining of $\sim 20 \%$ Sai1 cells. D, Quantile normalized gene expression (compiled from Illumina bead microarrays) (i) and qRT-PCR analysis (ii) of anteroposterior regional markers in hbNES and It-NES cells. Anterior hindbrain markers EN2 and GBX2 are consistently expressed, whereas forebrain (FOXG1 and OTX2) and caudal hindbrain (HOXB4, HOXB8, and HOXB9) are not expressed. $E$, qRT-PCR analysis of EN1/2 and GBX2 after treatment with FGF8 and Wnts for 2 passages (P1, Passage 1; P2, passage 2). F, Quantile normalized gene expression (compiled from Illumina bead chip microarrays) (i) and qRT-PCR analysis (ii) of dorsoventral markers in hbNES cells show expression of ventral intermediate marker IRX3, whereas expression of ventral markers (NKX6.1 and NKX2.2) and dorsal markers (PAX7 and MSX1) is low. G, NKX6.1 expression can be seen at the protein level in 3-4\% of cells. $\boldsymbol{H}-\boldsymbol{J}$, Differentiated hbNES cells express LIM1/2, LIM3, and ISLET1 consistent with V1-3 hindbrain interneurons and ventral motorneurons. $\boldsymbol{K}$, Rare TuJ1 neurons stain positive for 5-HT along axonal projections and cell body. Scale bars: $\boldsymbol{H}, \boldsymbol{I}, 100 \mu \mathrm{m} ; \boldsymbol{K}, 50 \mu \mathrm{m}$.
HB985) and cortical NS cells (CB660, CB171, and CB152) (Fig. $3 E)$. These transcriptome data confirm that hbNES cells are distinct from previously derived fetal NS cells and hindbrain NS-like cells derived from older embryos.

\section{Differentiation}

On removal of growth factors, hbNES cells differentiated asynchronously into Tuj1-positive neurons (80-90\%) and over 4 weeks formed elaborate neuronal networks (Fig. 4A,B). GFAPpositive and $\mathrm{S} 100 \beta$-positive astroglial cells (5-10\%) were also generated (Fig. 4B-D), and occasional O4-positive cells were detected, indicative of the oligodendrocyte lineage (Fig. $4 E$ ). The proportion of Tuj1 and GFAP-positive cells after differentiation was consistent for all hbNES cell lines (data not shown). Importantly, the predominantly neurogenic differentiation behavior was maintained after long-term culture (51 passages) and also after clonal expansion (Fig. 4I). The efficiency of neuronal differentiation is similar to that observed with lt-NES cells (Koch et al., 2009; Falk et al., 2012) and considerably higher than obtained with human NS cells (Sun et al., 2008). TuJ1-positive neurons began to appear 10-14 d after growth factor withdrawal, and networks of neurons persisted for $>6$ months. Aged neurons stained positively for the neuronal marker NeuN and markers of both glutamatergic (vGLUT2) and GABAergic (GABA) neurons (Fig. $4 F-H$ ). Whole-cell recordings on differentiated hbNES cells were performed after 2 months $(n=24)$ and 4 months $(n=14)$. The cells exhibited spontaneous action potentials $(20 \%$ at 2 months; $33 \%$ at 4 months) that were TTX-sensitive (Fig. 4J; Table $3)$. The amplitude and consistency of the action potentials increased after 4 months consistent with ongoing maturation. Neuronal processes at this time stained-positively for synaptophysin, a synaptic vesicle glycoprotein found in all mature synapses (Fig. $4 K$ ).

\section{Positional identity}

We investigated whether undifferentiated hbNES cell lines retained positional identity markers of the anterior hindbrain after long-term expansion. hbNES cells expressed EN1 and KROX20 mRNAs at levels comparable with those in primary anterior hindbrain tissue of 5-6 week fetuses (Fig. 5A). The presence of EN2 and KROX20 proteins was confirmed by immunohistostaining (Fig. 5B,C). GBX2 mRNA levels were somewhat higher than those in whole fetal hindbrain tissue. We then assessed the expression profile of anteroposterior identity markers using data from Illumina bead microarray platform (Fig. 5D). Interestingly, hbNES cells had a similar positional marker profile to lt-NES cells derived from pluripotent cells (Fig. 5D). Regional markers anterior to the isthmic organizer (OTX2 and FOXG1) were not expressed in any of hbNES cell lines (Fig. $5 A, D$ ). Markers of the caudal hindbrain and spinal cord (e.g., HOXB4, HOXB8, and HOXB9) were also not detected (Fig. 5D). However, anterior hindbrain markers EN2 and GBX2 were expressed in both hbNES and lt-NES cells (Fig. 5D). These findings were confirmed by qRT-PCR analysis (Fig. 5Dii). Interestingly, Sail NES cells that were derived from a large section of the hindbrain (extending beyond the ventral flexure) expressed HOXB2 mRNA (Fig. 5D, Sai1), but this was not detected in Sai2 and Sai3 NES cells, which originate from a region between the isthmus and the ventral flexure corresponding to rhombomere 1. HOXB2 mRNA was also found to be expressed in pluripotent-derived NES cell lines. We then tested the responsiveness of hbNES cells to morphogens that pattern the anterior hindbrain. Interestingly, cells cultured in FGF8 and Wnt1 upregulated EN1, EN2, and GBX2 mRNA (Fig. 

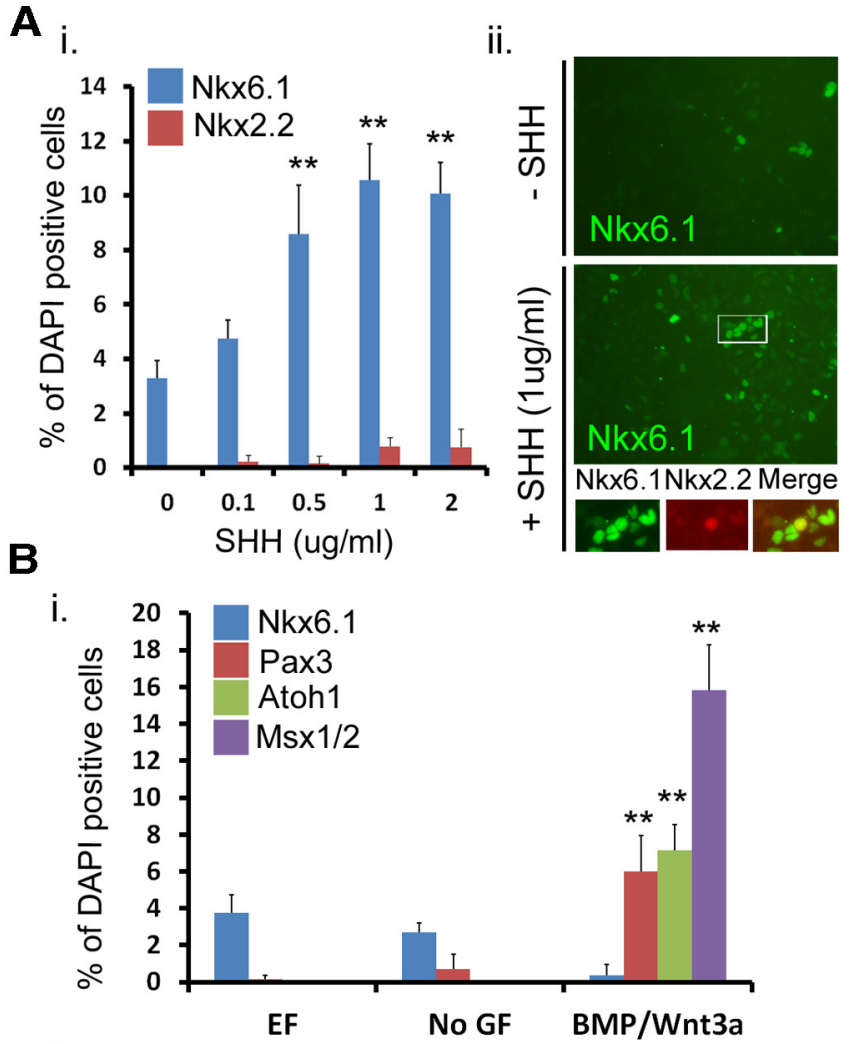

ii.
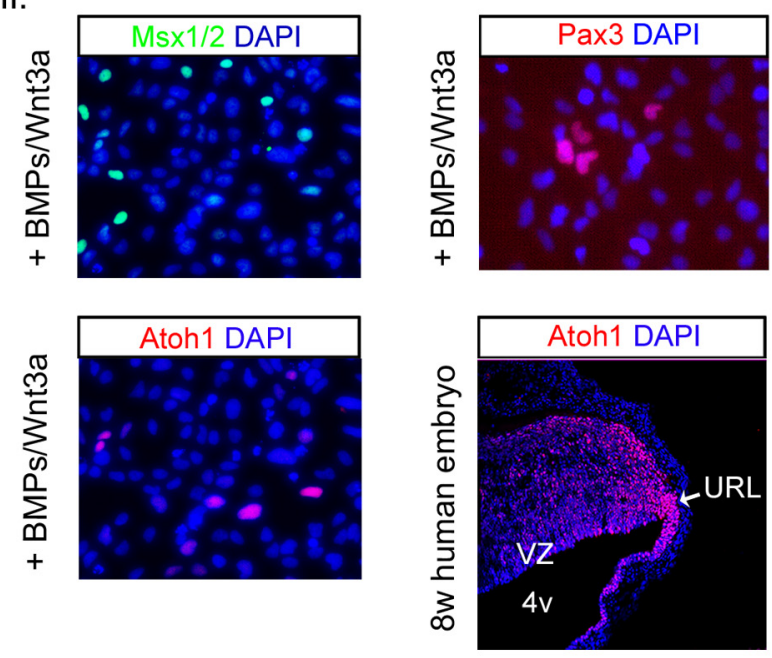

C

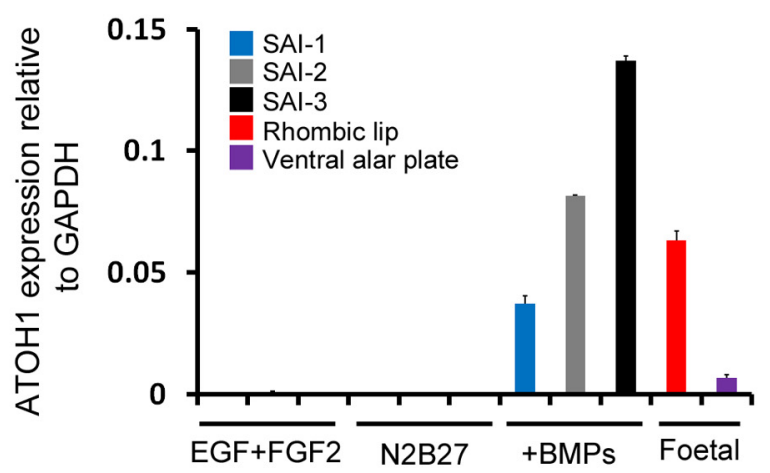

D

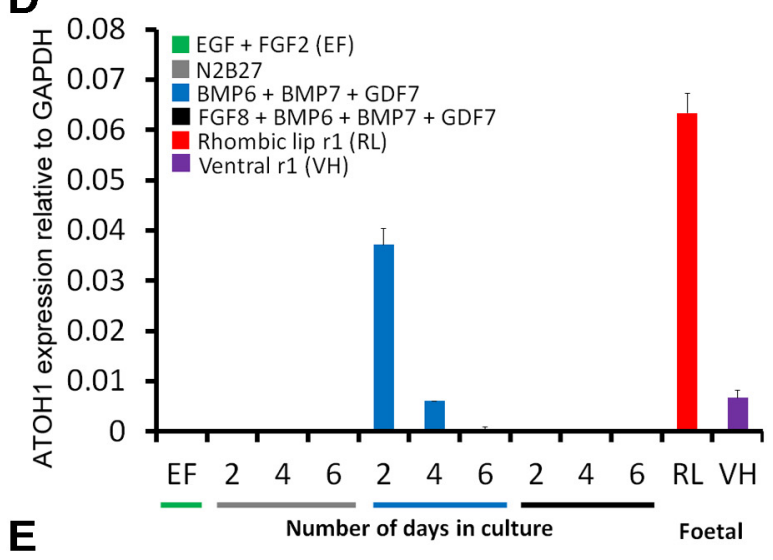

i.

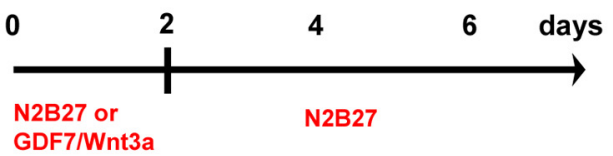

ii.
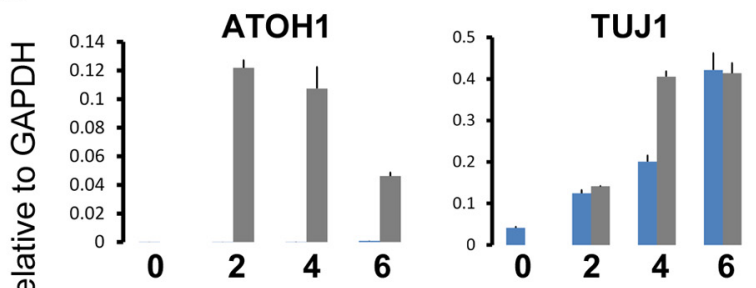

LHX9

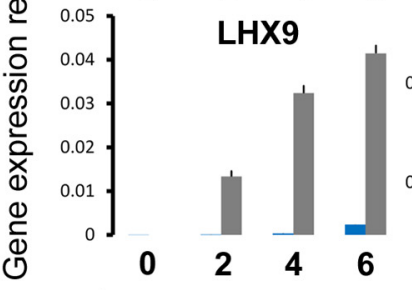

MEIS2

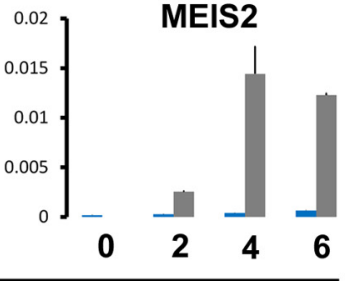

No. of days

N2B27

GDF7/Wnt3a
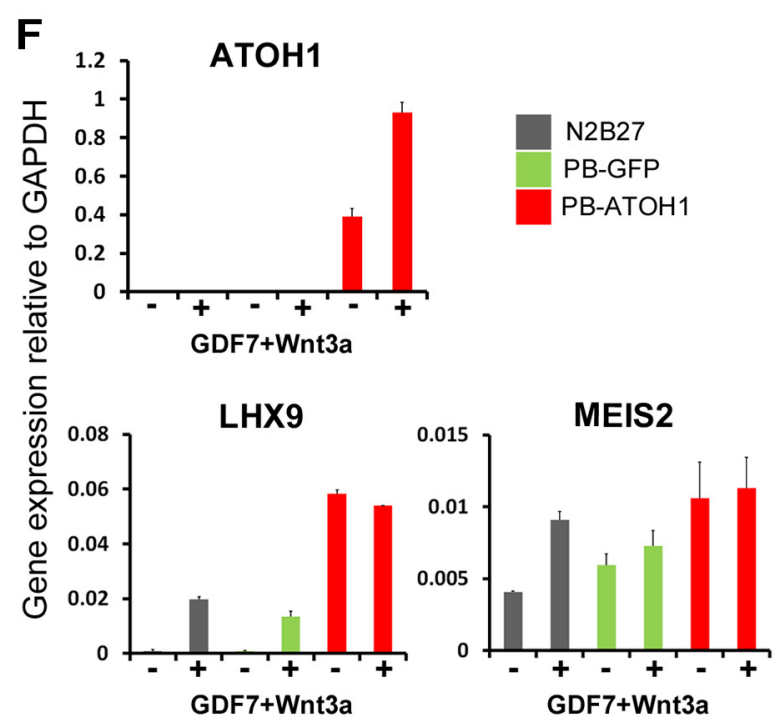

Figure 6. Responsiveness of hbNES cells to developmental signals of the anterior hindbrain domain. Ai, hbNES cells were exposed to different concentrations of SHH protein ( $\mu \mathrm{g} / \mathrm{ml})$. The percentage of cells expressing NKX6.1 increased from $3.2 \pm 0.7$ in the absence of SHH protein, to 4.7 $\pm 0.7,8.5 \pm 1.8,10.6 \pm 1.3$, and 10.1 \pm 1.2 after exposure to $0.1,0.5,1.0$, and 2.0 $\mu \mathrm{g} / \mathrm{ml}$ SHH protein, respectively. ${ }^{* *} p<0.01$ (Student's $t$ test). NKX2.2 is induced in the presence of SHH, although the percentage of positive cells is very low ( $\left.<1 \%\right)$. Aii, (Figure legend continues.) 
$5 E$ ). These findings suggest that hbNES cells retain the anteroposterior identity of their region of origin and responsiveness to signals produced by the isthmic organizer.

We also assessed dorsoventral identity. The gene expression profile showed that markers of the most ventral progenitors of the neural tube, such as NKX2.2 and OLIG2, were not detectable at the mRNA level in hbNES and lt-NES cell lines (Fig. 5F). NKX2.2 was also not detected by immunohistochemistry (Fig. $6 A$ ). NKX6.1, a marker of the ventral-intermediate neural tube, was very low at the mRNA level, but $\sim 3-4 \%$ of cells were positive by immunostaining. Other markers of the intermediate region, such as PAX6 and in particular IRX3, were more strongly expressed (Fig. 5F). qRT-PCR analysis of these dorsal and ventral markers was consistent with the array analysis (Fig. 5Fii). These findings suggest that, during self-renewal, the hbNES cell population has a mid-ventral character. Consistent with this, after 3-4 weeks of differentiation without any morphogen treatment, the majority of $\mathrm{TuJ} 1$-expressing neurons $(>80 \%)$ were positive for markers of V1-3 hindbrain interneurons, including LIM1/2, LIM3, which arise from intermediate domains of the hindbrain (Fig. $5 H, I$ ). In addition, a small percentage of neurons were positive for serotonin (5-HT) or the motor neuron marker ISLET-1 $(<1 \%)$ (Fig. 5J, K). These neurons are normally derived from the NKX2.2- and NKX6.1-expression domains (Pattyn et al., 2003), and therefore may arise from the Nkx6.1-positive subpopulation of hbNES cells.

\section{Developmental potency}

We examined whether hbNES cells would respond to developmental cues that specify the dorsoventral axis of the hindbrain. After treatment with $1 \mu \mathrm{g} / \mathrm{ml} \mathrm{SHH}$ for $2 \mathrm{~d}$, the fraction of NKX6.1-positive cells increased from $3-4 \%$ to $\sim 11 \%$ ( $p<0.01$, Student's $t$ test $)$ and NKX2.2 was induced in $\sim 1 \%$ of cells (Fig. 6Ai). Significantly, NKX2.2 was expressed within the NKX6.1 population, suggesting a coordinated ventralization response rather than independent gene expression (Fig. 6Aii). We also tested dorsalizing signals that emanate from the hindbrain roof plate (BMP7, BMP6, or GDF7 and Wnt3a). These factors caused a moderate decrease in the percentage of NKX6.1 cells and an induction of dorsal markers MSX1/2 (15\%), PAX3 (6\%), and ATOH1 (7\%) after $2 \mathrm{~d}$ of BMPs and Wnt3a (Fig. $6 B)(p<0.01$, Student's $t$ test $)$.

In mice, Atoh 1 expression in rhombomere 1 defines the upper rhombic lip (URL) from which cerebellar neurons arise. ATOH1 was also detected in the URL region of human embryos (Fig. 6Bii). ATOH1 mRNA was consistently induced in independent hbNES cell

\section{$\leftarrow$}

(Figure legend continued.) Coexpression of NKX6.1 and NKX2.2 is detected by immunostaining. Bi, The percentage of NKX6.1-positive cells decreases after exposure to BMP6, BMP7, or GDF7 and Wnt3a, whereas PAX3, MSX1/2, and ATOH1 expression is induced. ${ }^{* *} p<0.01$ (Student's $t$ test). Bii, Nuclear expression of MSX1/2, PAX3, and ATOH 1 is shown, and the expression of ATOH1 expression in the upper rhombic lip is confirmed on a sagittal section of $8 \mathrm{w}$ human embryo (VZ, Ventricular zone; $4 v$, fourth ventricle). C, BMPs consistently induce the expression of $A T O H 1$ in three independent hbNES cell lines. D, ATOH1 expression decreases after $>2 \mathrm{~d}$ treatment with BMP. Induction of ATOH1 does not occur in the presence of FGFs. Ei, Schematic diagram to show that hbNES cells were treated with GDF7 + Wnt3a and subsequently cultured in N2B27 base medium for 4 further days. Cells were analyzed by qRT-PCR on day 2, 4, and 6. Eii, ATOH1 expression decreases after $2 \mathrm{~d}$, whereas markers of deep cerebellar neurons LHX9 and MEIS2 continue to increase along with the neuronal differentiation marker TuJ1. $F$, hbNES cells (Sai2) were transiently transfected with a piggybac ATOH1 expression construct with a histidinol selection cassette (PB-ATOH1) and, subsequently, cultured in the presence of N2B27 and histidinol for $6 \mathrm{~d}$. qRT-PCR analyses of ATOH1, LHX9, and MEIS2 levels after $6 \mathrm{~d}$ of differentiation are shown. lines after exposure to BMPs (BMP6, BMP7, and GDF7) individually (data not shown) or in combination (Fig. $6 C$ ). Interestingly, induction of $A T O H 1$ was greater in cell lines that were derived from the most anterior part of the hindbrain (Sai2 and Sai3). ATOH1 expression was enhanced by Wnt3a (data not shown). ATOH1 mRNA decreased after 4 and $6 \mathrm{~d}$ of BMP exposure (Fig. 6D). Furthermore, ATOH1 was not expressed if FGF8 was added together with BMPs or if EGF and FGF2 were maintained (data not shown). Therefore, FGF signaling appears to counteract BMP stimulation.

The transient nature of ATOH1 expression after BMP exposure is reminiscent of early rhombic lip progenitors that migrate into the developing brainstem (Machold and Fishell, 2005; Wang et al., 2005). In mice, these cells upregulate Lhx9 and Meis2 and become neurons of the deep cerebellar nuclei (Morales and Hatten, 2006). Upon simple withdrawal of FGF2/EGF, differentiating hbNES cells do not express LHX9 or MEIS2 mRNA (Fig. 6E). However, after $\mathrm{BMP}$ and Wnt3a exposure, the expression of LHX9 and MEIS $2 \mathrm{mR}-$ NAs was readily detected during subsequent differentiation (Fig. 6Eii). The increase in these markers correlated inversely with decreasing ATOH1.

ATOH1 expression in the upper rhombic lip has previously been shown to be governed downstream of the BMP signaling (Alder et al., 1999; Timmer et al., 2002). To investigate this relationship further, we transiently transfected hbNES cells with an ATOH1 expression vector. We found that, after differentiation for $6 \mathrm{~d}$ in N2B27, LHX9, and, to lesser extent, MEIS2, mRNAs were induced in the absence of BMPs (Fig. 6F).

Collectively, these findings suggest that hbNES cells can respond to relevant dorsoventral signals, and differentiation can be steered into URL derivatives following developmental principles.

\section{Differentiation to cerebellar granule-like cells in vitro}

In rodents, the URL generates temporally discrete pools of neurons. At later stages (from $\sim$ E13.5 in mice), this germinal zone exclusively generates GCs, the most abundant neuron in the mammalian brain. Unlike the early-born progenitors, GC progenitors retain the expression of Atoh1 and migrate into the EGL (Wingate and Hatten, 1999; Wingate, 2001). We investigated whether hbNES cells maintain potency for the GC lineage. One of the characteristics of GC progenitors is their persistent capacity for proliferation, which continues even after birth (Wechsler-Reya and Scott, 1999). In mice, Atoh1positive cells persistently express the mitotic marker Ki67 from E13.5 onwards (Su et al., 2006). In contrast, Atoh $1^{+}$cells in other regions of the dorsal alar plate, such as the lower rhombic lip, or spinal cord, are mostly postmitotic from E11 (Akazawa et al., 1995; Ben-Arie et al., 2000). The early-born upper rhombic lip progenitors of precerebellar neurons are also generally Ki67-negative (Su et al., 2006). We investigated whether $\mathrm{Ki}^{+} 7^{+}$progenitors persisted in the ATOH $1^{+}$ population after BMP treatment. We found that, after $4 \mathrm{~d}$ of BMP/ Wnt3a treatment, a small proportion of cells (1\%) retain the expression of ATOH1 and continue to express Ki67 (Fig. 7A). This observation encouraged us to investigate whether hbNES cells may have competence to form later-stage rhombic lip derivatives.

GC differentiation is known to depend on both an intrinsic program and the influence of adjacent GCs and other cell types in the developing cerebellum (Trenkner et al., 1984; Wechsler-Reya and Scott, 1999; Dahmane and Ruiz i Altaba, 1999). Accordingly, previous studies have used coculture techniques to achieve maturation of GCs in vitro (Nakatsuji and Nagata, 1989; Gao et al., 1992; Yamasaki et al., 2001). We derived a GFP-expressing hbNES cell line (Sai3GFP) by stably transfecting the cells with a piggybac GFP expression vector. After $2 \mathrm{~d}$ of BMP and Wnt3a treatment, the GFP-hbNES cells were mixed 1:100 with GCs freshly isolated from P4-P8 mouse neo- 
A

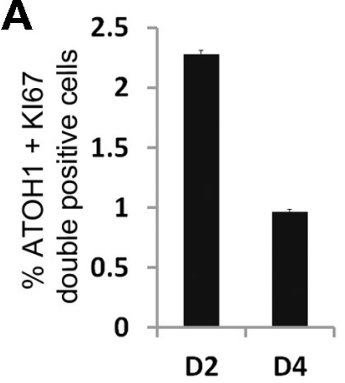

B

(i)

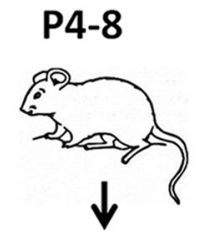

Isolate GNPs

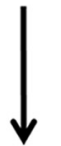

Co-culture (ratio 1:100)

(ii)

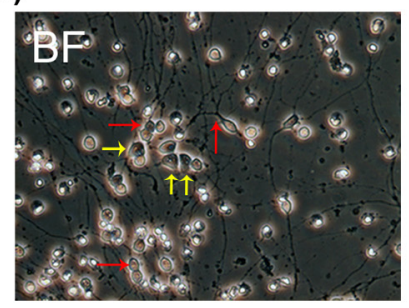

C
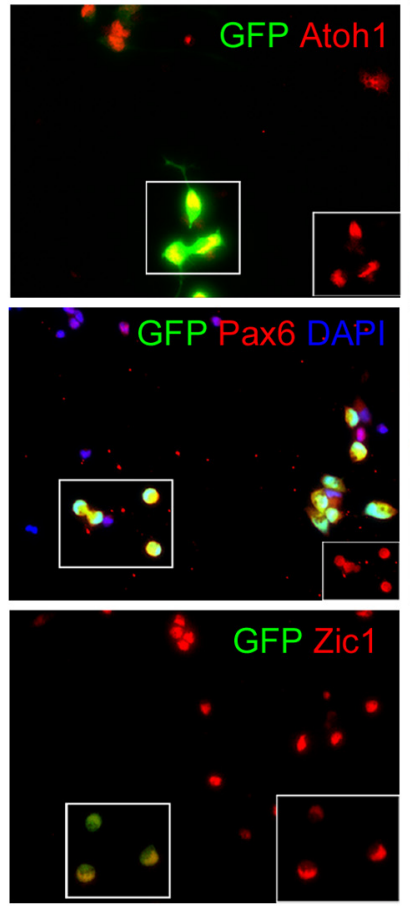

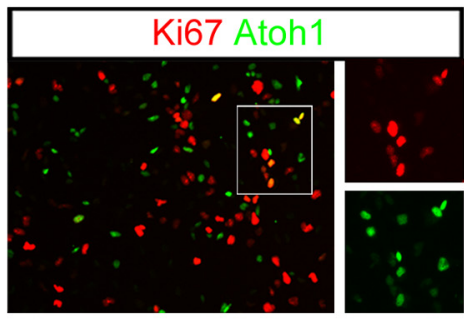

GFP-hindbrain NES

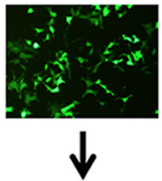

BMP/Wnt3a

$48 \mathrm{~h}$
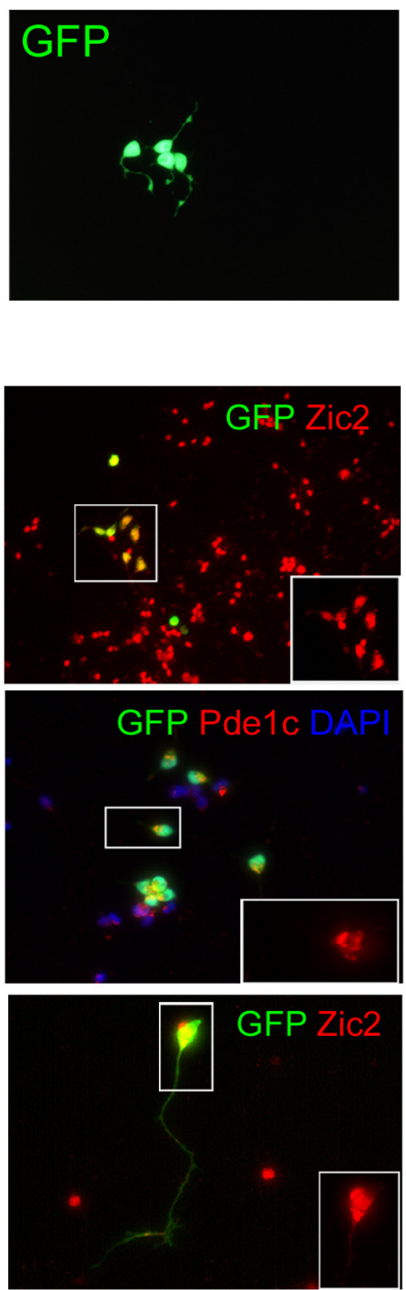

D
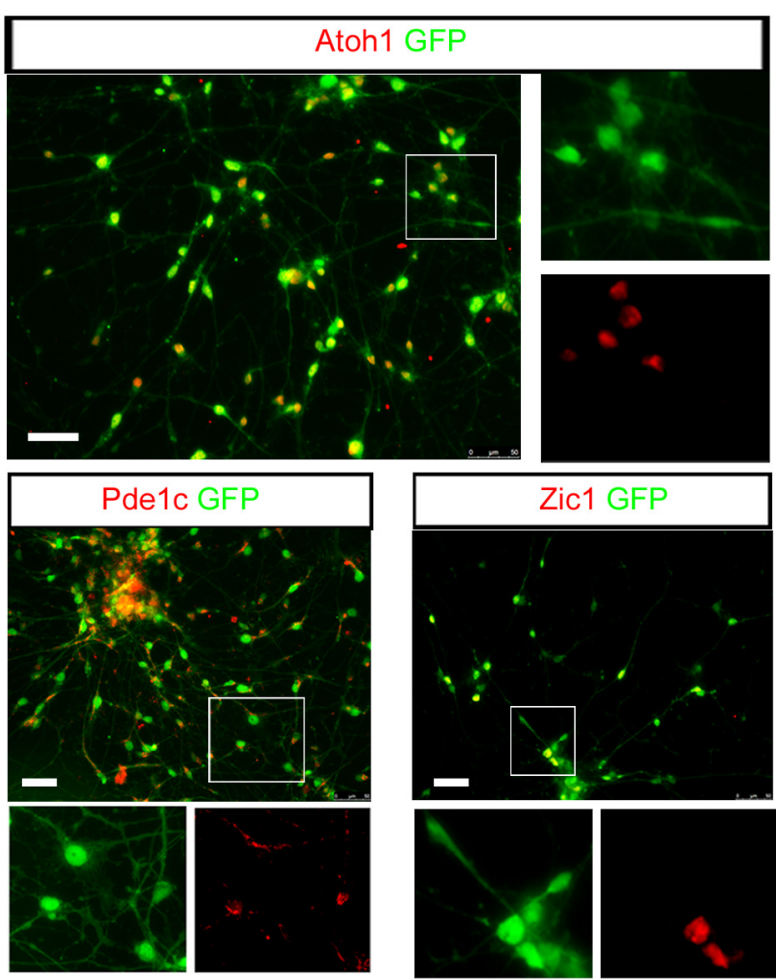

E
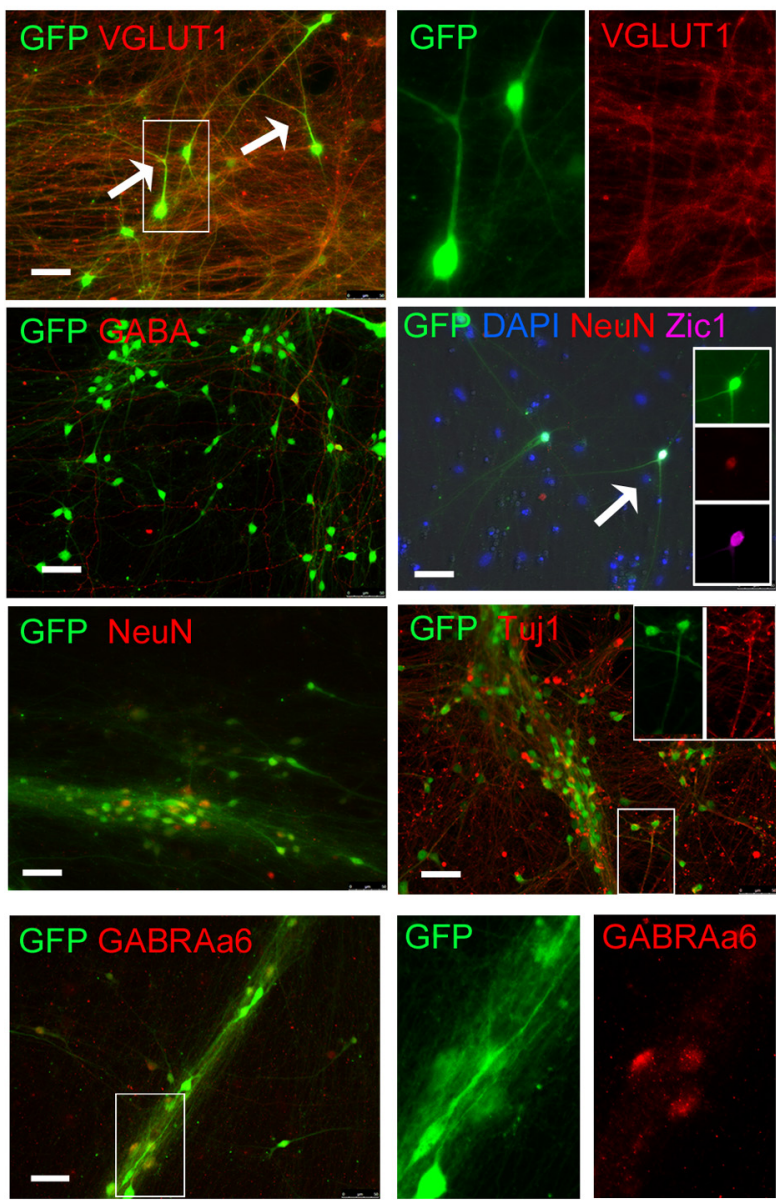

Figure 7. Generation of cerebellar granule-like cells after coculture with mouse GCs. A, BMP-treated hbNES cells were differentiated in N2B27 media without growth factors for 4 further days. Cells were analyzed by immunohistochemistry on day 2 (D2) and day 4 (D4). A small proportion of ATOH1-positive cells continues to express the proliferation marker Ki67 ( 1\% ATOH1 and Ki67 double-positive cells at day 4). Bi, GFP-labeled hbNES cells were treated with GDF7 and Wnt3a for $48 \mathrm{~h}$, and then cocultured at single-cell density with freshly isolated (Figure legend continues.) 
nates and plated. After $2 \mathrm{~d}$ of coculture, the morphology of GFPhbNES cells (Fig. 7B, yellow arrows in brightfield) began to resemble that of mouse GCs (Fig. 7B, red arrows in brightfield). They formed small clusters that expressed markers of GCs, including ATOH1, ZIC2, PAX6, PDE1c, and ZIC1 (Morales and Hatten, 2006; Salero and Hatten, 2007) (Fig. 7C).

In the absence of the mouse GC feeders, BMP/Wnt3a-treated hbNES cells either died or differentiated at single cell density (data not shown). However, in the presence of mouse GC feeders, they continued to proliferate and form larger clusters (Fig. $7 D$ ). We followed their behavior after coculture with mouse GCs over 3 months. Cell clusters continued to express nuclear ATOH1 as well as ZIC1 and Pdelc at 4 weeks (Fig. 7D). By this time, almost all mouse GCs had died but human cell viability was high. At 3 months, the majority of cells $(>80 \%)$ had small, round cell bodies and extended long axonal projections (Fig. 7E). Numerous neurons displayed bifurcated neurites (Fig. $7 E$, white arrows), which were reminiscent of $\mathrm{T}$-shaped granule neuron parallel fibers. Most of these neurons expressed vGLUT1 (80-90\%) (Fig. 7E), and only $5 \%$ were positive for GABA (Fig. 7E). In addition, typical markers of mature granule neurons, including NeuN, Zic1, and GABA-A receptor $\alpha 6$ (GABR $\alpha 6$ ), were detected in these cultures (Fig. 7E). TuJ1 was strongly expressed in $>90 \%$ of cells (Fig. $7 E$ ). These results show that hbNES are capable of generating granule-like neurons, although a prolonged maturation period may be needed for complete differentiation.

\section{Engraftment potential}

We then asked whether BMP-treated hbNES cells would survive, differentiate, and integrate in the cerebellum in vivo. GFP-labeled or unlabeled hbNES cells were treated for $2 \mathrm{~d}$ with BMPs and Wnt3a and transplanted either into the fourth ventricle of E13-E15 rat embryos in utero or into the developing cerebellum of P1-P3 neonatal rats. The recipient cerebella were analyzed at different postnatal ages, from P7 to P30.

Transplantation to fetal or postnatal hosts yielded similar results. GFP-positive cells, or cells stained with anti-human specific nuclei antibody, were found in 11 of $22(50 \%)$ recipient cerebella after postnatal injections and 5 of $25(20 \%)$ recipient cerebella after in utero injection. In each case, there was minimal disturbance to the normal appearance and architecture of the cerebellum, and we detected no overt signs of overgrowth or tumor formation (Fig. 8A,B). The animals showed no evidence of ataxia or other neurological signs.

The majority of donor cells were located in the white matter, where they formed thick clusters or discrete chains aligned to axonal tracts (Fig. 8C,D). These cells typically displayed bipolar shapes and extended neurites (Fig. 8D,E, white arrow) bearing prominent growth cones. The neurites navigated through the axial white matter of the cerebellar lobules for considerable distances (Fig. 8G) and also entered the cerebellar peduncles. In addition, smaller clusters of transplanted cells were found on the pial surface of the recipient

\footnotetext{
$\leftarrow$

(Figure legend continued.) mouse GCs for $2 \mathrm{~d}$. Bii, GFP-hbNES cells (yellow arrows, GFPpositive) acquire a similar morphology to mouse GCs (red arrows) after $2 \mathrm{~d}$ of coculture. $C$, Clusters of granule-like cells are generated after $2 \mathrm{~d}$ of coculture with mouse $\mathrm{GCs}$ and express ATOH1, PAX6, ZIC1, ZIC2, and PDE1C. D, The cocultured hbNES cells continue to expand and express $\mathrm{GC}$ markers ATOH1, Pde1c, and Zic1 after 1 month. At this stage, the mouse GCs have all died. $\boldsymbol{E}$, Three months after coculture with mouse GCs, single hbNES cells have expanded and differentiated into neurons with bifurcated neurites (white arrows) reminiscent of T-shaped granule neurons, and predominantly express VGLUT1. Only few neurons express GABA. Mature neurons also expressed NeuN, Zic1, and Tuj1 and the granule neuron marker GABRA $\alpha 6$. Scale bars: $\mathbf{D}, \boldsymbol{E}, 50 \mu \mathrm{m}$.
}

cerebellar cortex (Figure 8C,F, blue arrows). From both of these locations, a minor fraction of transplanted cells migrated and/or sent processes into the cortical layers (Fig. 8C,D,F,H,I, white arrows). The GFP-positive axons appeared beaded, rarely branched, and exhibited long trajectories through the recipient molecular and granular layers (Fig. $8 I-M$ ). The neuronal processes were generally longer at later time points of analysis (e.g., day 30 after transplant). GFP-positive cells also showed fusiform shapes and were either radially oriented across the molecular layer or dispersed along the granular-molecular layer interface (Fig. 8I,J,N). Interestingly, at earlier analysis times, many cells in the white matter were positive for Ki67 (Fig. 8G), whereas those in the cortical layers were mostly negative. The latter were often positive for doublecortin, a marker of migratory neuroblasts and immature neurons (Fig. $8 \mathrm{~K}-\mathrm{N}$ ) (Gleeson et al., 1999).

To assess neuronal identity further, we examined markers for different populations of cerebellar neurons. Although some donor cells could be stained with calretinin antibodies (Fig. 8Y), they were never positive for PAX2 or parvalbumin (data not shown), thus excluding GABAergic phenotypes. On the other hand, the vast majority of the donor cells $(>90 \%)$, both clustered in the white matter and scattered in the cortical layers, expressed ATOH1, ZIC1, ZIC2, and Pde1c, markers for the GC lineage (8Fig. 8D,E,O-S) (Ben-Arie et al., 1997; Aruga et al., 1998, 2002). However, only a minority of the transplanted cells expressed markers typical of mature GCs, such as NeuN (Fig. $8 T, U$ ) or vglut1 (Fig. 8V,W). In addition, a few cells in the region of the deep cerebellar nuclei expressed TBR1, a marker of deep cerebellar neurons (data not shown) and VGLUT1 (Fig. 8X). Transplanted cells rarely showed morphological features of glial cells and did not colocalize with GFAP cells (Fig. 8P).

In summary, these experiments indicate that transplanted hbNES cells engraft in the host cerebellum and within 4 weeks differentiate predominantly into neuronal precursors or immature neurons that express ATOH1 and other GC lineage markers. Although they do not acquire fully mature GC phenotypes in this time period, they show impressive abilities for survival, differentiation, and extensive axonal growth into the recipient tissue.

\section{Discussion}

In this study, we have derived and characterized stable neuroepithelial stem cell lines from the CNS of Carnegie stage 15-17 (week 5-7) human embryos. hbNES cells retain regional specification and high neurogenic capacity even after long-term culture. These cells generate hindbrain-specific cell fates, including derivatives of the cerebellar rhombic lip, in vitro and in vivo.

hbNES cells are characterized by the following: (1) expression of neuroepithelial and neural rosette markers with absence of neuronal and glial markers; (2) long-term expansion and clonogenicity; (3) constant and high neurogenic differentiation; (4) hindbrain identity and responsiveness to developmental signals; and (5) survival, integration, and differentiation capacity in the developing rat brain. Once established, hbNES cells can be massively expanded and cryopreserved, and are therefore suitable for producing human neurons for in vitro neurobiology, drug discovery, or transplantation (Danovi et al., 2010; Fujimoto et al., 2012; McLaren et al., 2012).

Self-renewal of hbNES cells is driven by EGF and FGF2. FGF has previously been shown to induce major transcriptional changes in neural progenitors and might generate a synthetic neural stem cell phenotype (Gabay et al., 2003; Pollard et al., 2008) that may not fully reflect an in vivo state (Conti and Cattaneo, 2010). However, our data suggest that a distinct progenitor stage can be captured using these growth factors and retain developmental specification. Indeed, 


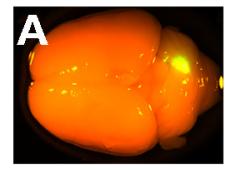

B GFP ZIC1 DAPI
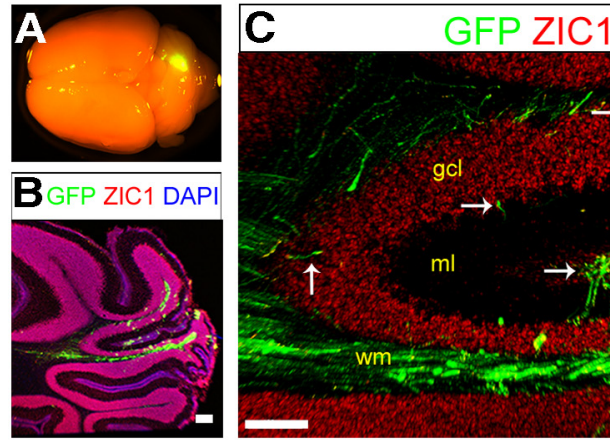

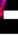
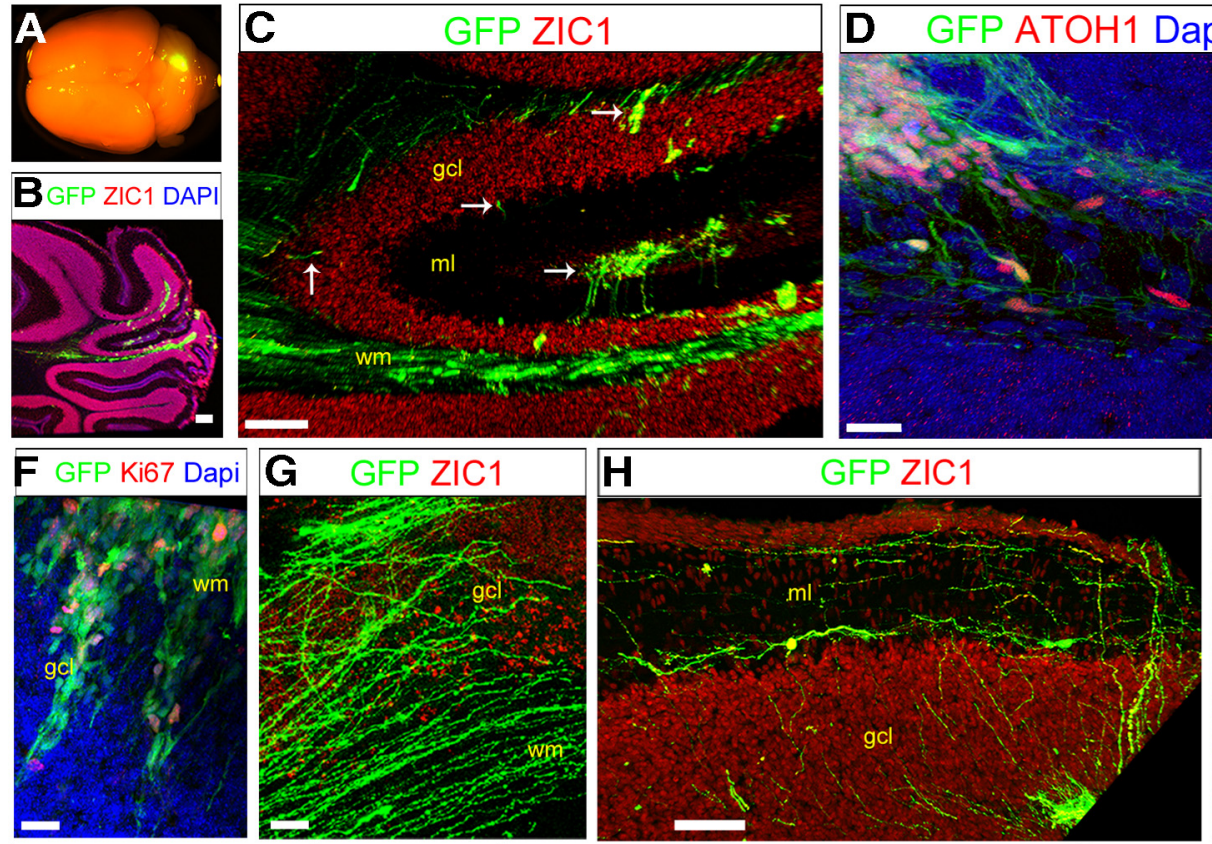

$\mathrm{gcl}$

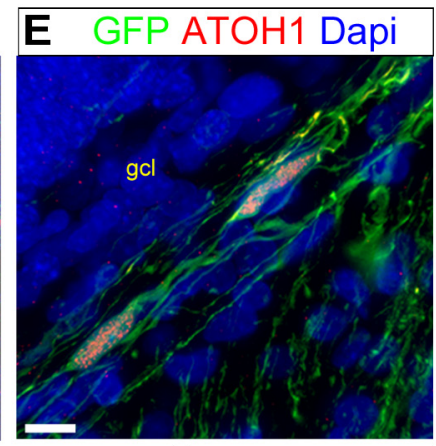

I GFP NeuN Dapi J GEP NeuN Dapi
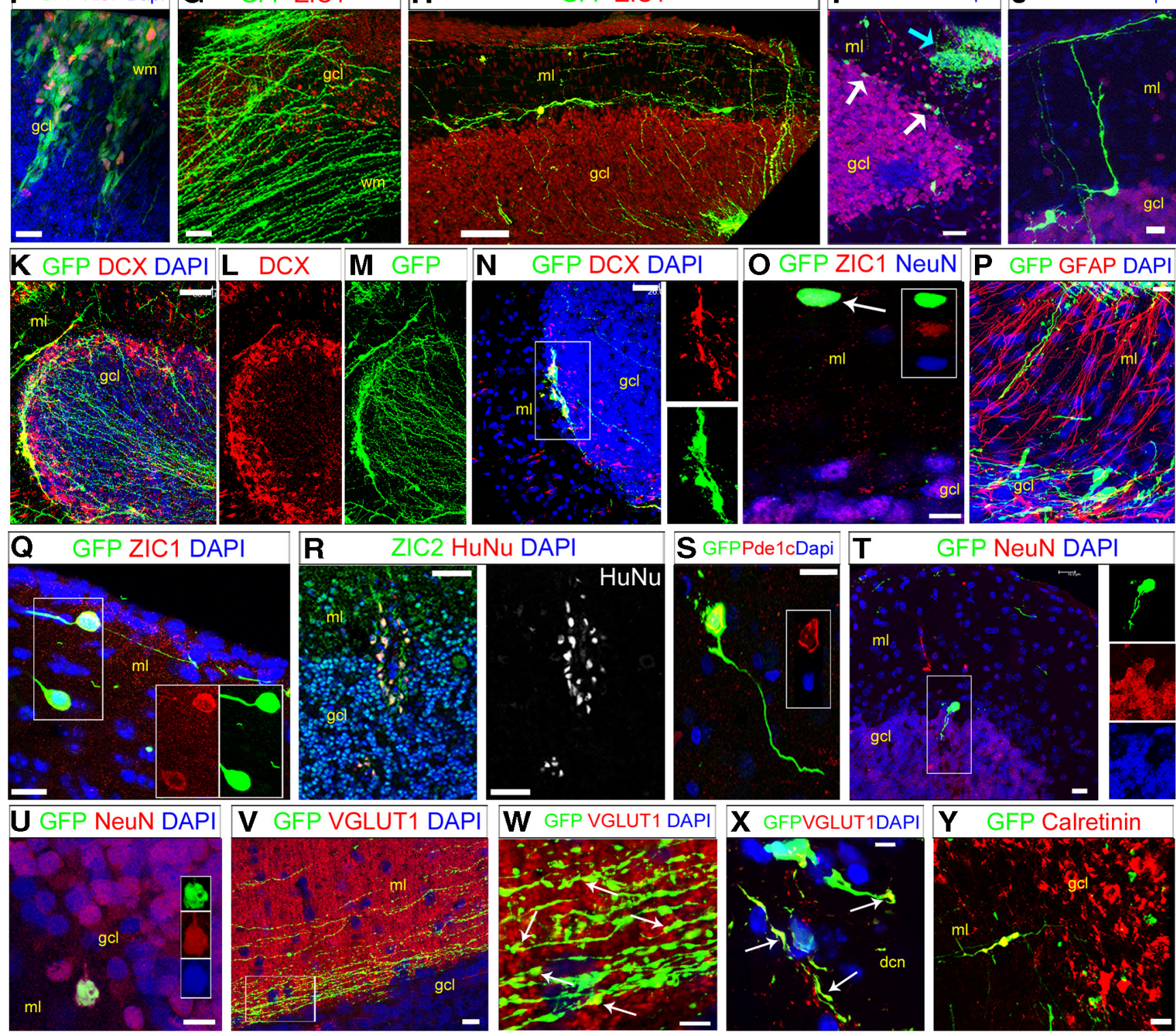

Figure 8. Engraftment of hbNES cells in the developing rat cerebellum. GFP-labeled hbNES cells were treated with BMPs and Wnt3a for 2 d and then injected in P1-P3 neonatal rats or into E13-E15 rat embryos in utero. The cells were analyzed on day $7(\boldsymbol{A}-\boldsymbol{F})$, day $21(\mathbf{G}-\boldsymbol{N})$, and day $30(\boldsymbol{O}-\boldsymbol{\eta}) \cdot \boldsymbol{A}$, Postnatal recipient cerebella showed normal size and morphology. $\boldsymbol{B}, \boldsymbol{C}$, Grafted cells were mostly located in the recipient white matter, with several elements migrating through the cortex (C, white arrows). $\boldsymbol{D}, \boldsymbol{E}$, Cells in the graft homogeneously expressed ATOH1 ( $>90 \%)$. $\boldsymbol{F}$, A fraction of GFP-positive cells in the white matter was positive for Ki67, whereas those migrating to the granular layer were predominantly negative. $\boldsymbol{G}, \boldsymbol{H}$, At day 21 after transplant, grafted cells exhibit extending neuronal fibers that run for long distances through the host white matter $(\boldsymbol{G})$, and also passed through the cortical layers $(\boldsymbol{H})$. $\boldsymbol{I}, \mathbf{I n}$ some cases, clusters of transplanted cells were found on the pial cerebellar surface (I, light blue arrow) and from there cells migrate through the recipient cerebellar cortex (I, white arrows). J-N, A few transplanted cells were positioned at the molecular layer and granular layer interface and were frequently labeled by anti-doublecortin $(D C X)(\boldsymbol{K}-\boldsymbol{N}$, red). These cells express several markers shared by cerebellar $\mathrm{GCS}$, as Zic $(\mathbf{0}, \mathbf{Q}$, red), Zicz $(\boldsymbol{R}$, green), $\operatorname{Pde} 1$ ( $(\boldsymbol{S}$, red), and NeuN ( $\boldsymbol{O}$, blue; $\boldsymbol{T}, \boldsymbol{U}$, red). $\boldsymbol{P}$, Grafted cells did not stain positive for GFAP. $\boldsymbol{V}, \boldsymbol{W}$, Some varicosities of the axonal projections in the host molecular layer were immunopositive for Vglut-1 ( $\boldsymbol{W}$, arrows). A similar pattern was found in the deep cerebellar nuclei $(\boldsymbol{X}$, arrow). Calretinin-positive cells were rarely found near the Purkinje cell layer $(\boldsymbol{\eta})$. $\mathrm{ml}, \mathrm{Molecular}$ layer, gcl, $\mathrm{GC}$ layer; wm, white matter. Scale bars: $\boldsymbol{P}, \boldsymbol{W}, \boldsymbol{X}, 5 \mu \mathrm{m} ; \boldsymbol{E}, \mathbf{O}, \mathbf{S}, \boldsymbol{U}, 10 \mu \mathrm{m} ; \boldsymbol{J}, \mathbf{Q}, \boldsymbol{T}, \boldsymbol{V}, 15 \mu \mathrm{m} ; \boldsymbol{D}, \boldsymbol{F}, \boldsymbol{R}, 20 \mu \mathrm{m} ; \boldsymbol{N}, 25 \mu \mathrm{m} ; \boldsymbol{G}, \boldsymbol{I}, \boldsymbol{Y}, 30 \mu \mathrm{m} ; \boldsymbol{H}, \boldsymbol{K}-\boldsymbol{M}, 50 \mu \mathrm{m} ; \boldsymbol{B}, \boldsymbol{C}, 100 \mu \mathrm{m}$. 
hbNES cells could be derived only during a brief developmental window (Carnegie 15-18, week 5-7). Cultures derived from slightly older fetuses (Carnegie >18) under the same conditions developed different features reminiscent of radial-glia like NS cells (Sun et al., 2008). hbNES cells exhibit properties that are consistent with late neuroepithelial progenitors, including the expression of SOX1 and markers enriched in neural rosettes (DACH1, PLZF, and ZO-1), robust neurogenesis, and responsiveness to developmental cues. Although changes induced by the environment are an important consideration in any culture system, our observations suggest that the properties of hbNES cells are largely inherited from the founder neural progenitor cell specification. The failure to recover them from fetal hindbrain older than 7 weeks (Carnegie 17-18) is consistent with the marker analyses indicating that human neural progenitors may undergo a major developmental transition during this period.

Neural rosettes have frequently been highlighted in approaches to derive neural progeny from embryonic stem cells (Zhang et al., 2001; Elkabetz et al., 2008; Chambers et al., 2009; Koch et al., 2009). These structures, comprising radially organized columnar neuroepithelial cells, appear responsive to developmental signals, in contrast to more mature progenitors (Elkabetz et al., 2008). Rosettes can be converted into lt-NES cells (Koch et al., 2009) that retain key properties, including the formation of rosette-like patterns, apical-basal polarity, expression of markers, such as SOX1, PLZF, MMNR1, and DACH1, and high neurogenic potency. lt-NES cells can readily be derived from different pluripotent cell lines, including iPS cells of different genetic backgrounds (Falk et al., 2012). However, their neurodevelopmental relevance may be questioned, in particular because they are suggested to arise via respecification of an initial anterior identity (Koch et al., 2009). The apparent similarity of hbNES cells to lt-NES cells derived from human ES and iPS cells is therefore striking. In this context, hbNES cells may be a useful benchmark for validating pluripotent stem cell derived lt-NES cells from normal or diseased backgrounds.

hbNES cells broadly retain the identity of their region of origin, as shown by the expression of hindbrain markers and the generation of hindbrain-specific neurons, such as serotonin neurons. Moreover, they show responsiveness to developmentally relevant signals in vitro. SHH induces NKX2.2 and NKX6.1, consistent with its role in the specification of ventral cell fates in the mouse hindbrain (Ye et al., 1998; Hynes et al., 2000). More pronounced is the induction of dorsal markers MSX1/2, PAX3, and ATOH1 in response to BMPs and Wnt3a. This is also in line with mouse studies that showed induction of ATOH1 and cerebellar fates in ventral explants of the anterior hindbrain in response to BMPs (Alder et al., 1999; Chizhikov et al., 2006). Together, these results suggest that hbNES cells exhibit developmental flexibility within the hindbrain domain, even after longterm passaging.

In vitro differentiation and in vivo grafting show that, after exposure to BMPs and Wnt3a, hbNES cells exhibit potency for both early-born and later-stage URL fates. After treatment with BMPs and Wnt $3 \mathrm{a}, L H X 9$ and MEIS2 are robustly induced in differentiating hbNES cells, consistent with early-born DCN progenitors. We also found that a small proportion of cells retain expression of ATOH1 protein and continue to proliferate, similar to GCs. Moreover, the grafted hbNES cells express distinctive markers of the GC lineage, and a small proportion show morphological features and behavior similar to those of rodent GCs grafted to syngeneic cerebella (Carletti et al., 2002; Williams et al., 2008). Notably, like primary GCs, they form clusters of proliferating progenitors that settle into the recipient white matter or on the cortical surface and extend long neurites through the host tissue. Unlike primary mouse GCs, however,
hbNES cells display inefficient migration into cortical layers, either inwardly from the pial surface or outwardly from the white matter (Williams et al., 2008). This inability to enter the recipient cerebellar cortex, which could result from undefined cross-species barriers, may impede the generation of mature granule neurons from hbNES cells because this process is crucial for granule neuron morphogenesis in vivo (Chédotal, 2010). Nevertheless, we found that coculturing BMP-treated hbNES cells with primary mouse GCs in vitro resulted in the development of cerebellar granule-like neurons, as previously described for differentiation from mouse ES cells (Su et al., 2006; Salero and Hatten, 2007). These hbNES cell-derived neurons acquired typical morphology and mature traits of granule neurons after 3 months. Together, these results demonstrate that hbNES cells maintain competence for cerebellar rhombic lip neurogenesis.

Cerebellar development has been studied using transgenic mouse models (Ben-Arie et al., 1997; Machold and Fishell, 2005; Wang et al., 2005), but no representative cell lines have been established from rodents. hbNES cells therefore offer a new system for experimentally dissecting the molecular regulation of cerebellar cell specification and differentiation. Propagation of region-specific neuroepithelial cells also raises interesting prospects for modeling tumor formation. Recent studies show that tumor phenotypes are, to some extent, dictated by the originating neural cells (Swartling et al., 2012). hbNES cells may have value in modeling tumors that arise in the GC lineage, such as medulloblastoma. More broadly, hbNES cells represent a scalable resource for generation of human neurons without genetic manipulation or complex culture systems. They may therefore be used to study generic properties of human neurons. In particular, their defined origin and identity may prove a useful complement to iPS cell-derived NES cells in defining normal versus disease phenotypes.

\section{Notes}

The URL for the supplemental movie "Hindbrain NES cells (Sai1) cultured in EGF and FGF2" is http://upload.sms.cam.ac.uk/media/1506157.

\section{References}

Akazawa C, Ishibashi M, Shimizu C, Nakanishi S, Kageyama R (1995) A mammalian helix-loop-helix factor structurally related to the product of Drosophila proneural gene atonal is a positive transcriptional regulator expressed in the developing nervous system. J Biol Chem 270:8730-8738. CrossRef Medline

Alder J, Lee KJ, Jessell TM, Hatten ME (1999) Generation of cerebellar granule neurons in vivo by transplantation of BMP-treated neural progenitor cells. Nat Neurosci 2:535-540. CrossRef Medline

Aruga J, Minowa O, Yaginuma H, Kuno J, Nagai T, Noda T, Mikoshiba K (1998) Mouse Zicl is involved in cerebellar development. J Neurosci 18:284-293. Medline

Aruga J, Inoue T, Hoshino J, Mikoshiba K (2002) Zic2 controls cerebellar development in cooperation with Zic1. J Neurosci 22:218-225. Medline

Ben-Arie N, Bellen HJ, Armstrong DL, McCall AE, Gordadze PR, Guo Q, Matzuk MM, Zoghbi HY (1997) Math1 is essential for genesis of cerebellar granule neurons. Nature 390:169-172. CrossRef Medline

Ben-Arie N, Hassan BA, Bermingham NA, Malicki DM, Armstrong D, Matzuk M, Bellen HJ, Zoghbi HY (2000) Functional conservation of atonal and Math1 in the CNS and PNS. Development 127:1039-1048. Medline

Carletti B, Grimaldi P, Magrassi L, Rossi F (2002) Specification of cerebellar progenitors after heterotopic-heterochronic transplantation to the embryonic CNS in vivo and in vitro. J Neurosci 22:7132-7146. Medline

Carpenter MK, Cui X, Hu ZY, Jackson J, Sherman S, Seiger A, Wahlberg LU (1999) In vitro expansion of a multipotent population of human neural progenitor cells. Exp Neurol 158:265-278. CrossRef Medline

Cattaneo E, Magrassi L, Butti G, Santi L, Giavazzi A, Pezzotta S (1994) A short term analysis of the behaviour of conditionally immortalized neuronal progenitors and primary neuroepithelial cells implanted into the fetal rat brain. Brain Res Dev Brain Res 83:197-208. CrossRef Medline

Chambers SM, Fasano CA, Papapetrou EP, Tomishima M, Sadelain M, 
Studer L (2009) Highly efficient neural conversion of human ES and iPS cells by dual inhibition of SMAD signaling. Nat Biotechnol 27:275-280. CrossRef Medline

Chédotal A (2010) Should I stay or should I go? Becoming a granule cell. Trends Neurosci 33:163-172. CrossRef Medline

Chizhikov VV, Lindgren AG, Currle DS, Rose MF, Monuki ES, Millen KJ (2006) The roof plate regulates cerebellar cell-type specification and proliferation. Development 133:2793-2804. CrossRef Medline

Conti L, Cattaneo E (2010) Neural stem cell systems: physiological players or in vitro entities? Nat Rev Neurosci 11:176-187. CrossRef Medline

Dahmane N, Ruiz i Altaba A (1999) Sonic hedgehog regulates the growth and patterning of the cerebellum. Development 126:3089-3100. Medline

Danovi D, Falk A, Humphreys P, Vickers R, Tinsley J, Smith AG, Pollard SM (2010) Imaging-based chemical screens using normal and gliomaderived neural stem cells. Biochem Soc Trans 38:1067-1071. CrossRef Medline

Elkabetz Y, Panagiotakos G, Al Shamy G, Socci ND, Tabar V, Studer L (2008) Human ES cell-derived neural rosettes reveal a functionally distinct early neural stem cell stage. Genes Dev 22:152-165. CrossRef Medline

Falk A, Koch P, Kesavan J, Takashima Y, Ladewig J, Alexander M, Wiskow O, Tailor J, Trotter M, Pollard S, Smith A, Brüstle O (2012) Capture of neuroepithelial-like stem cells from pluripotent stem cells provides a versatile system for in vitro production of human neurons. PloS One 7:e29597. CrossRef Medline

Fujimoto Y, Abematsu M, Falk A, Tsujimura K, Sanosaka T, Juliandi B, Semi K, Namihira M, Komiya S, Smith A, Nakashima K (2012) Treatment of a mouse model of spinal cord injury by transplantation of human induced pluripotent stem cell-derived long-term self-renewing neuroepitheliallike stem cells. Stem Cells 30:1163-1173. CrossRef Medline

Gabay L, Lowell S, Rubin LL, Anderson DJ (2003) Deregulation of dorsoventral patterning by FGF confers trilineage differentiation capacity on CNS stem cells in vitro. Neuron 40:485-499. CrossRef Medline

Gao WQ, Liu XL, Hatten ME (1992) The weaver gene encodes a nonautonomous signal for CNS neuronal differentiation. Cell 68:841-854. CrossRef Medline

Gleeson JG, Lin PT, Flanagan LA, Walsh CA (1999) Doublecortin is a microtubule-associated protein and is expressed widely by migrating neurons. Neuron 23:257-271. CrossRef Medline

Götz M, Huttner WB (2005) The cell biology of neurogenesis. Nat Rev Mol Cell Biol 6:777-788. CrossRef Medline

Guo G, Yang J, Nichols J, Hall JS, Eyres I, Mansfield W, Smith A (2009) Klf4 reverts developmentally programmed restriction of ground state pluripotency. Development 136:1063-1069. CrossRef Medline

Hatten ME (1985) Neuronal regulation of astroglial morphology and proliferation in vitro. J Cell Biol 100:384-396. CrossRef Medline

Hynes M, Ye W, Wang K, Stone D, Murone M, Sauvage F, Rosenthal A (2000) The seven-transmembrane receptor smoothened cell-autonomously induces multiple ventral cell types. Nat Neurosci 3:41-46. CrossRef Medline

Koch P, Opitz T, Steinbeck JA, Ladewig J, Brüstle O (2009) A rosette-type, self-renewing human ES cell-derived neural stem cell with potential for in vitro instruction and synaptic integration. Proc Natl Acad Sci U S A 106: 3225-3230. CrossRef Medline

Lu Q, Sun EE, Flanagan JG (2004) Analysis of PDZ-RGS3 function in ephrin-B reverse signaling. Methods Enzymol 390:120-128. CrossRef Medline

Machold R, Fishell G (2005) Math1 is expressed in temporally discrete pools of cerebellar rhombic-lip neural progenitors. Neuron 48:17-24. CrossRef Medline

McKay R (1997) Stem cells in the central nervous system. Science 276: 66-71. CrossRef Medline

McLaren D, Gorba T, Marguerie de Rotrou A, Pillai G, Chappell C, Stacey A, Lingard S, Falk A, Smith A, Koch P, Brüstle O, Vickers R, Tinsley J, Flanders D, Bello P, Craig S (2013) Automated large-scale culture and medium-throughput chemical screen for modulators of proliferation and viability of human induced pluripotent stem cell-derived neuroepitheliallike stem cells. J Biomol Screen 18:258-268. CrossRef Medline

Morales D, Hatten ME (2006) Molecular markers of neuronal progenitors in the embryonic cerebellar anlage. J Neurosci 26:12226-12236. CrossRef Medline

Nakatsuji N, Nagata I (1989) Paradoxical perpendicular contact guidance displayed by mouse cerebellar granule cell neurons in vitro. Development 106:441-447. Medline
O’Rahilly R, Muller F (1987) Developmental stages in human embryos (Meriden-Stinehour). Meriden, Connecticut: Carnegie Institution of Washington.

Pattyn A, Vallstedt A, Dias JM, Samad OA, Krumlauf R, Rijli FM, Brunet JF, Ericson J (2003) Coordinated temporal and spatial control of motor neuron and serotonergic neuron generation from a common pool of CNS progenitors. Genes Dev 17:729-737. CrossRef Medline

Pevny LH, Sockanathan S, Placzek M, Lovell-Badge R (1998) A role for SOX1 in neural determination. Development 125:1967-1978. Medline

Pollard SM, Wallbank R, Tomlinson S, Grotewold L, Smith A (2008) Fibroblast growth factor induces a neural stem cell phenotype in foetal forebrain progenitors and during embryonic stem cell differentiation. Mol Cell Neurosci 38:393-403. CrossRef Medline

Reynolds BA, Rietze RL (2005) Neural stem cells and neurospheres-reevaluating the relationship. Nat Methods 2:333-336. CrossRef Medline

Sah DW, Ray J, Gage FH (1997) Bipotent progenitor cell lines from the human CNS. Nat Biotechnol 15:574-580. CrossRef Medline

Salero E, Hatten ME (2007) Differentiation of ES cells into cerebellar neurons. Proc Natl Acad Sci U S A 104:2997-3002. CrossRef Medline

Su HL, Muguruma K, Matsuo-Takasaki M, Kengaku M, Watanabe K, Sasai Y (2006) Generation of cerebellar neuron precursors from embryonic stem cells. Dev Biol 290:287-296. CrossRef Medline

Sun Y, Pollard S, Conti L, Toselli M, Biella G, Parkin G, Willatt L, Falk A, Cattaneo E, Smith A (2008) Long-term tripotent differentiation capacity of human neural stem (NS) cells in adherent culture. Mol Cell Neurosci 38:245-258. CrossRef Medline

Suslov ON, Kukekov VG, Ignatova TN, Steindler DA (2002) Neural stem cell heterogeneity demonstrated by molecular phenotyping of clonal neurospheres. Proc Natl Acad Sci U S A 99:14506-14511. CrossRef Medline

Svendsen CN, ter Borg MG, Armstrong RJ, Rosser AE, Chandran S, Ostenfeld T, Caldwell MA (1998) A new method for the rapid and long term growth of human neural precursor cells. J Neurosci Methods 85:141-152. CrossRef Medline

Swartling FJ, Savov V, Persson AI, Chen J, Hackett CS, Northcott PA, Grimmer MR, Lau J, Chesler L, Perry A, Phillips JJ, Taylor MD, Weiss WA (2012) Distinct neural stem cell populations give rise to disparate brain tumors in response to N-MYC. Cancer Cell 21:601-613. CrossRef Medline

Timmer JR, Wang C, Niswander L (2002) BMP signaling patterns the dorsal and intermediate neural tube via regulation of homeobox and helix-loophelix transcription factors. Development 129:2459-2472. Medline

Trenkner E, Smith D, Segil N (1984) Is cerebellar granule cell migration regulated by an internal clock? J Neurosci 4:2850-2855. Medline

Vescovi AL, Parati EA, Gritti A, Poulin P, Ferrario M, Wanke E, FrölichsthalSchoeller P, Cova L, Arcellana-Panlilio M, Colombo A, Galli R (1999) Isolation and cloning of multipotential stem cells from the embryonic human CNS and establishment of transplantable human neural stem cell lines by epigenetic stimulation. Exp Neurol 156:71-83. CrossRef Medline

Walton NM, Sutter BM, Chen HX, Chang LJ, Roper SN, Scheffler B, Steindler DA (2006) Derivation and large-scale expansion of multipotent astroglial neural progenitors from adult human brain. Development 133:3671-3681. CrossRef Medline

Wang VY, Rose MF, Zoghbi HY (2005) Math1 expression redefines the rhombic lip derivatives and reveals novel lineages within the brainstem and cerebellum. Neuron 48:31-43. CrossRef Medline

Wechsler-Reya RJ, Scott MP (1999) Control of neuronal precursor proliferation in the cerebellum by Sonic Hedgehog. Neuron 22:103-114. CrossRef Medline

Williams IM, Carletti B, Leto K, Magrassi L, Rossi F (2008) Cerebellar granule cells transplanted in vivo can follow physiological and unusual migratory routes to integrate into the recipient cortex. Neurobiol Dis 30:139-149. CrossRef Medline

Wingate RJ (2001) The rhombic lip and early cerebellar development. Curr Opin Neurobiol 11:82-88. CrossRef Medline

Wingate RJ, Hatten ME (1999) The role of the rhombic lip in avian cerebellum development. Development 126:4395-4404. Medline

Yamasaki T, Kawaji K, Ono K, Bito H, Hirano T, Osumi N, Kengaku M (2001) Pax6 regulates granule cell polarization during parallel fiber formation in the developing cerebellum. Development 128:3133-3144. Medline

Yan J, Xu L, Welsh AM, Hatfield G, Hazel T, Johe K, Koliatsos VE (2007) 
Extensive neuronal differentiation of human neural stem cell grafts in adult rat spinal cord. PLoS Med 4:e39. CrossRef Medline

Ye W, Shimamura K, Rubenstein JL, Hynes MA, Rosenthal A (1998) FGF and Shh signals control dopaminergic and serotonergic cell fate in the anterior neural plate. Cell 93:755-766. CrossRef Medline
Ying QL, Smith AG (2003) Defined conditions for neural commitment and differentiation. Methods Enzymol 365:327-341. CrossRef Medline

Zhang SC, Wernig M, Duncan ID, Brüstle O, Thomson JA (2001) In vitro differentiation of transplantable neural precursors from human embryonic stem cells. Nat Biotechnol 19:1129-1133. CrossRef Medline 